\title{
A Panel VAR Approach on Analyzing Non-Performing Loans in the Turkish Banking Sector
}

Vuslat Us*

\begin{abstract}
This paper examines non-performing loans (NPLS) using the Turkish banking sector data by a panel vector autoregression (VAR) approach for the period between 2002Q4 and 2017Q4. The panel VAR analysis is used to test the existence of interdependencies among major bank-level variables and macroeconomic indicators. Given earlier evidence on changing dynamics of NPLs in Turkey after the global crisis, the analysis is repeated by sub-periods covering the pre-crisis and the post-crisis periods as a robustness check. Overall, the panel VAR confirms the existence of strong feedback effects among the selected variables. Also, the robustness check supports the presence of feedback effects and also verifies the changing dynamics of NPLs by producing more significant responses compared to the benchmark model. Furthermore, the robustness analysis shows that NPLs are more responsive to macroeconomic conditions in the post-crisis period. Despite the evidence for changing dynamics, capital adequacy, profitability and efficiency still feature out as important bank-specific variables, the impulses of which produce significant and plausible responses in NPLs in all cases. Likewise, NPLs respond reasonably and strongly to shocks in fundamental macroeconomic indicators like inflation, GDP growth, unemployment and debt stock. In this regard, the analysis of impulse-response functions reveals that a positive shock to growth leads to the reduction of NPLs while higher inflation, unemployment and debt stock lead to higher NPLs as expected. Future studies may focus on the underlying structural forces driving the NPLs, which, however, is beyond the scope of this paper.
\end{abstract}

Keywords: Non-performing loans, Turkish banking sector, Panel VAR, Profitability, Impulse-response functions, Inflation.

JEL Classification: C23, E44, E52, G10, G21.

\section{Öz - Türk Bankacılık Sektöründe Takipteki Kredilerin Panel VAR Yaklaşımıyla İncelenmesi}

Bu çalışmada takipteki krediler 2002Ç4 ve 2017ç4 dönemine ilişkin Türk bankacılık sektörü verileri kullanılarak panel vektör otoregresyon (VAR) yaklaşımıyla incelenmektedir. Panel VAR analizi banka düzeyinde değişkenler ve makroekonomik göstergeler arasındaki karşılıklı bağımlılıkları test etmek amacıyla kullanılmaktadır. Küresel krizden sonra Türkiye ekonomisinde takipteki alacakların dinamiklerinin değiştiğine dair daha önceki bulgular göz önüne alınarak, sağlamlık testi olarak analiz kriz öncesi ve kriz sonrası dönemleri kapsayan alt dönemler itibarıla tekrarlanmaktadır. Genel olarak, panel VAR modeli seçilen değişkenler arasında güçlü geribildirim etkilerinin varlığını doğrulamaktadır. Ayrıca, sağlamlık kontrolü geribildirim etkilerinin varlığını desteklemekte ve baz modele kıyasla daha anlamlı tepkiler üreterek takipteki kredilerin değişen dinamiklerini doğrulamaktadır. Ayrıca, sağlamlık analizi, takipteki kredilerin kriz sonrası dönemde makroekonomik koşullara daha duyarlı olduğunu göstermektedir. Takipteki kredilerin dinamiklerinin değiştiğine ilişkin bulgulara rağmen, sermaye yeterliliği, kârlılık ve verimlilik gibi bankaya özgü önemli değişkenlere ilişkin şokların her durumda takipteki kredilerde anlamlı ve makul tepkilere yol açtığı görülmektedir. Benzer şekilde, takipteki krediler enflasyon, GSYiH büyümesi, işsizlik ve borç stoku gibi temel makroekonomik göstergelerdeki şoklara da makul ve güçlü tepki vermektedir. Bu bağlamda, etki-tepki fonksiyonlarının analizi takipteki kredilerin pozitif büyüme şokuna azalarak; enflasyon, işsizlik ve borç stokundaki artışa ise beklendiği gibi artarak cevap verdiğini göstermektedir. İleride yapılacak çalışmalarda, takipteki kredileri belirleyen yapısal etkenlere odaklanılmasının faydalı olduğu düşünülmekle birlikte bu konu şu aşamada çalışmanın kapsamı dışında yer almaktadır.

Anahtar Kelimeler: Takipteki krediler, Türk bankacılık sektörü, Panel VAR, Kârlıık, Etki-tepkifonksiyonları, Enflasyon.

JEL Sınıflandırması: C23, E44, E52, G10, G21.

\footnotetext{
* Central Bank of the Republic of Turkey, Research and Monetary Policy Department - E-mail: vuslat.us@tcmb.gov.tr ORCID ID: https://orcid.org/0000-0002-9531-4381
}

Article Received: 19.04.2020Ａrticle Accepted: 01.06.2020ＤOI: http://dx.doi.org/10.46520/bddkdergisi.789935 


\section{Introduction}

Worsening loan quality is a major risk to banking sector as well as the overall financial system. In this respect, one important indicator in evaluating loan quality is non-performing loans (NPLs). In particular, Reinhart and Rogoff (2011) argue that the rise in NPLs can be used to mark the onset of a banking crisis, while Sorge (2004) states that NPLs can be treated as a benchmark to test the vulnerability of the financial system. In addition, Demirguc-Kunt and Detragiache (1998) and Bar et al. (1994) discuss that increasing NPLs are the most common precursors of banking crises. This is because failing institutions have large proportions of NPLs prior to failure, and asset quality is a significant predictor of insolvency (Demirguc-Kunt, 1989; Whalen, 1991; and Siems and Barr, 1994).

Accordingly, exploring the determinants of NPLs is critical. This is especially true after the global financial crisis, an era dominated by the spillovers of the unconventional policy tools implemented by major central banks. These unconventional policies had negative repercussions on emerging market economies since they led to massive capital flows, rapid credit growth and higher NPLs.

Specifically, Erdinç and Abazi (2014) report that the emerging Europe has been hit severely by the crisis due to higher NPLs accumulated after the crisis. Aiyar et al. (2015) state that the crisis has left many countries with elevated levels of NPLs, especially in southern parts of the euro area as well as in Eastern and Southeastern Europe. Similarly, Jassaud and Kang (2015) discuss that rising NPLs in Italy continue to weigh on banks' balance sheets since the onset of the crisis. Hence, identifying factors that drive NPLs is essential particularly in the post-crisis era.

There is a wide strand of literature that analyzes NPLs by various factors. These range from bank-specific indicators to macroeconomic aggregates. In this regard, Berger and DeYoung (1997), Podpiera and Weill (2008) and Sinkey and Greenawalt (1991) are important works that analyze NPL dynamics by mostly relating them with banks' efficiency, while Berge and Boye (2007), Boss et al. (2009) and Cifter et al. (2009) explain problem loans through their links with the macroeconomic environment. On the other hand, Greenidge and Grosvenor (2010), Salas and Saurina (2002), Jiménez and Saurina (2006) and Louzis et al. (2012), among many others, attempt to investigate the NPL dynamics using both bank-specific and macroeconomic factors as possible explanatory variables. 
While these studies analyze NPLs for a single country using either aggregate or bank-level data, there are also studies that analyze NPLs for a panel of countries. Accordingly, Rinaldi and Sanchis-Arellano (2006), Espinoza and Prasad (2010) and Boudriga et al. (2009) are featuring works while Ozili (2019) and Radivojević et al. (2019) are the latest studies along this line.

In addition, there is another array of literature where NPL dynamics are explained by a range of institutional variables such as regulations, governance and supervision as well as global factors that account for the changes in external financial conditions. In this regard, Breuer (2006) and Barth et al. (2004) are pioneering studies that analyze NPLs, whereas Us (2018) and Amin et al. (2019) are more latest attempts along this vein.

Meanwhile, some recent studies have looked at the feedback effects from NPLs to these variables. This is because of the possibility that NPLs may not only be driven by these factors but also affect these variables in turn. In particular, using different country samples, Espinoza and Prasad (2010), Love and Ariss (2014), Nkusu (2011), Klein (2013), Belgrave et al. (2012), Beaton et al. (2016), among several others, analyze the feedback effects in NPLs and find that NPLs are responsive to various shocks either originating from internal (bank-specific) or external (macroeconomic or industry-specific) factors, and these factors may also respond to $s$ cks in NPLs.

The significance of feedback effects is especially important to the Turkish economy given that Turkish banks were also exposed to mounting credit risks associated with higher NPLs after the global crisis. In fact, CBRT (2010), Selçuk (2010) and Afşar (2011) report that there has been a rapid increase in NPLs following the crisis. Moreover, Us $(2016,2017,2018)$ demonstrate that the global crisis changed the dynamics of NPLs in the Turkish banking sector.

Since the banking sector constitutes an immense part of the domestic financial system in Turkey, an in-depth analysis of the determinants of NPLs via feedback effects is necessary for identifying key vulnerabilities of the financial stability via its interaction with the macroeconomic environment. Specifically, the Turkish economy has been exposed to immense capital flows after the global crisis due to unconventional expansionary monetary policies employed by advanced economies. This led to rapid credit growth, thereby posing risks on financial stability (IMF, 2012; Kara, 2013). 
Against this background, the Central Bank of the Republic of Turkey (CBRT) was prompted to search for an alternative monetary policy framework that has focused on containing the adverse effects of accelerating credits, short-term capital inflows and the associated macro financial risks with a particular emphasis on credit and exchange rate channels (Başçı and Kara, 2011). Hence, an inquiry into this issue is also crucial for the Turkish economy in terms of its implications regarding the implementation of the monetary policy, which also addresses macro prudential concerns.

Against this background, this paper aims to contribute to the existing literature on NPLs in Turkey by analyzing NPLs via feedback effects. In accordance with the current literature, the analysis is conducted through panel vector autoregression (VAR) approach. Similar to standard VAR models, the panel VAR ${ }^{1}$ model allows for all variables in the system to affect each other. This implies that the framework takes into account all possible interactions between the variables in the model simultaneously. Yet, unlike standard VAR that uses aggregate data, the panel VAR technique has the advantage of using micro (bank-level) data. Hence, this is the first attempt, at least to our knowledge, to examine the interdependencies and feedback effects among NPLs, bank-specific factors and macroeconomic variables in Turkey. Also, given the evidence provided by Us $(2016,2017,2018)$ that the dynamics of NPLs have changed after the global crisis, the paper performs a robustness check for analyzing the pre-crisis and the post-crisis periods separately.

Overall, the contribution of the paper is threefold: First, the panel VAR methodology allows to analyze how NPLs respond to shocks stemming from the banking sector and the macroeconomic environment in Turkey. Second, this framework helps to assess how the banking system and the macroeconomic conditions react to shocks in NPLs. Third, the robustness check shows whether NPLs respond differently before and after the global financial crisis.

The paper is organized as follows: The next section presents the literature review about the determinants of NPLs and the feedback effects. The following section describes the econometric methodology, the data selection, the empirical results for the benchmark model and the robustness check, while the succeeding section discusses the results. Finally, the last section concludes this paper. All tables and figures are given in the Appendix.

1 Canova and Ciccarelli (2013) provide an extensive survey on the use of panel VAR models. 


\section{The Literature Review about the Determinants of NPLs and Feedback Effects}

The analysis of credit risk and the determinants of NPLs is an important theme that has been elaborated frequently in the literature. As discussed in the last section, the growing attention on this subject has been centered on two major strands. One strand has suggested bank-specific (internal) variables as potential determinants of credit risk, while the other strand has concentrated on external variables such as economic conditions, regulations, global variables etc. as possible determinants of NPLs. In addition, there is a consensus about the existence of feedback effects among these variables and the NPLs. Against this background, this section discusses briefly about these determinants and feedback effects.

\subsection{Bank-Specific Determinants}

NPL dynamics are affected by bank-specific factors that cause risky lending behavior. In this regard, the capital adequacy (regulatory capital or capital requirement) of a bank is an important determinant of NPLs. Berger and DeYoung (1997) analyze United States (U.S.) commercial banks and report a negative link between capital requirement and NPLs based on the moral hazard hypothesis. This postulates that banks with low capital respond to moral hazard incentives by increasing the riskiness of their loan portfolio, which results in higher NPLs. Investigating a large sample of U.S. banks over the 1979-1985 period, Keeton and Morris (1987) also argue that banks with relatively higher capital are reluctant to grant high risk loans, which in turn results in lower NPLs. Likewise, Salas and Saurina (2002) find an inverse relation between capital adequacy and NPLs using data for Spanish commercial and savings banks in the period 1985-1997.

On the other hand, by using a panel of 59 countries over the period 2002-2006, Boudriga et al. (2009) show that regulatory capital has a positive impact on loan quality only in countries with better enforcement of laws. Analyzing commercial banks of a diverse set of emerging and advanced countries for the period 19922002, Ahmad and Ariff (2007) also find a positive relation between regulatory capital and the NPL ratio, concluding that banks increase their capital as a cushion against credit risk losses.

2 Berger and DeYoung (1997) explain bad loans by possible hypotheses relating NPLs to efficiency and capital adequacy. In particular, the bad luck hypothesis links NPLs to exogenous events. The bad management hypothesis ascribes NPLs to poorly run banks because of inefficiency at cost control, loan underwriting and monitoring. The skimping hypothesis asserts that NPLs are higher if banks economize on loan underwriting and monitoring. Moral hazard hypothesis relates higher NPLs with lower capital adequacy. 
Bank lending is also a significant bank-specific determinant of NPLs. In this respect, Keeton and Morris (1987) argue that banks venturing into excess lending may end up with higher impaired loans. Utilizing data on commercial banks in the U.S. during the 1984 to 1987 period, Sinkey and Greenawalt (1991) assert that banks with greater risk appetite may endure higher NPLs as well. Salas and Saurina (2002) and Jiménez and Saurina (2006) also report higher NPLs for increased bank lending for Spanish commercial banks. Yet, NPLs may also be reversely linked to lending. In particular, Vithessonthi (2016) observe an adverse relation between lending and NPLs for Japanese commercial banks after the global financial crisis, and this reverse relation is attributed to the adoption of stringent lending standards.

The efficiency of a bank is another important bank-specific determinant of NPLs. Based on the bad management hypothesis, Berger and DeYoung (1997) argue that decreases in measured cost efficiency lead to increased future problem loans. Podpiera and Weil (2008) examine the relationship between efficiency and bad loans in the Czech banking industry and also find evidence for the bad management hypothesis. Hence, the authors conclude that inefficiency leads to higher NPLs due to poor loan underwriting, monitoring and cost control. Meanwhile, Espinoza and Prasad (2010) and Louzis et al. (2012) also find support for this hypothesis. On the other hand, using NPL data for Central and Eastern European countries from 1995 to 2002, Rossi et al. (2008) provide evidence for the skimping hypothesis which conjectures a positive relation between cost efficiency and NPLs. This implies that banks which devote less effort to ensure higher loan quality are more cost-efficient, yet they carry higher number of NPLs in the long run.

Profitability is another important bank-specific determinant of NPLs as better managed banks are believed to have higher quality assets. In this regard, analyzing NPLs by a loan category breakdown using commercial bank data in Greece, Louzis et al. (2012) propose the bad management II hypothesis, which associates lower profitability with higher NPLs. However, based on Spanish banks' data, GarcíaMarco and Robles-Fernández (2008) find that higher profitability is accompanied with increased risk and higher NPLs. This can be attributed to procyclical credit policy, which implies that better performance may generate future increases in NPLs as it reflects liberal credit policy on the part of the bank.

Asset size is also a crucial bank-specific determinant of NPLs. Stern and Feldman (2004) assert that large-sized banks are more likely to take risk by granting loans even to lower quality borrowers. They argue that too-big-to-fail banks may indulge in 
excessive risk taking as these banks are more likely to be rescued by the government in case of a failure. However, examining Taiwanese banks, Hu et al. (2004) report a negative relation between asset size and NPLs and argue that larger banks have a better chance to evaluate loans. Meanwhile, Salas and Saurina (2002) also defend the presence of a negative relation between asset size and NPLs, attributing this to the diversification hypothesis, i.e. bigger size allows for more diversification opportunities.

\subsection{Macroeconomic Determinants}

Domestic macroeconomic conditions establish a link between business cycle and banking performance as changes in macroeconomic conditions are likely to directly affect the borrower's ability to service debt. In this respect, the expansionary phase of the cycle is characterized by a low NPL ratio as the capability of borrowers to repay their stock of debt increases during this cycle. As the boom continues, however, some risks may accumulate as credit is extended also to lower quality debtors, and consequently, when the contractionary phase sets in, NPLs rise.

Against this backdrop, Gross Domestic Product (GDP) growth is often found to have a negative correlation with NPLs, confirming the countercyclical properties of NPLs. Salas and Saurina (2002) and Jiménez and Saurina (2006) discuss that this countercyclical behavior of NPLs can be explained by the fact that higher growth implies improved debt servicing capacity of borrowers. On the other hand, a slowdown in the economy raises unemployment, and this increases NPLs.

Similarly, unemployment is also a relevant factor explaining NPLs. Rinaldi and Sanchis-Arellano (2006) observe a strong correlation between NPLs and unemployment in European countries. Berge and Boye (2007) find that NPLs are sensitive to unemployment in the Nordic banking system. Louzis et al. (2012) argue that unemployment has a significant impact on all NPL categories in Greece with business NPLs being the most sensitive. This shows that firms cut their labor cost before they face debt servicing problems. Additionally, unemployment is a leading indicator of consumer NPLs, and this implies that a rise in unemployment affects households' ability to service their debt.

Inflation is also assessed to be a significant determinant of NPLs. Yet, its effect on NPLs is ambiguous. More specifically, higher inflation can make debt servicing easier by reducing the real value of the outstanding loan, hence it can reduce NPLs. However, higher inflation lowers the borrowers' real income when wages are sticky, 
and this may obviously push up NPLs. In fact, investigating NPLs in the sub-Saharan Africa, Fofack (2005) observes a positive relation between inflation and NPLs. On the other hand, Khemraj and Pasha (2009) report a negative link between inflation and NPLs using data for Guyanese banks.

Policy rate is a significant policy-related determinant of NPLs as it gauges the effect of the monetary policy. In particular, interest rate hikes affect the ability to service debt. Bofondi and Ropele (2011) state that a policy rate hike is likely to be passed through to lending rates, and this transmission should raise NPLs. Espinoza and Prasad (2010) also argue that NPLs rise when interest rate increases. Similarly, Sinkey and Greenawalt (1991) report a positive correlation between NPLs and interest rates. Meanwhile, Berge and Boye (2007) find that NPLs are highly sensitive to real interest rates as well.

The change in exchange rate is another crucial determinant of NPLs. In this regard, the depreciation of the local currency might have a negative impact on loan repayment. This effect is even stronger in countries with a large amount of lending in foreign currency to unhedged borrowers. In this context, Kalluci and Kodra (2010) and Moinescu and Codirlaşu (2012) report that the real effective exchange rate is an explanatory macroeconomic variable of the NPL ratio for Albanian and Romanian banks, respectively. On the other hand, Castro (2013) analyzes the credit risk determinants in GIPSI countries (Greece, Ireland, Portugal, Spain and Italy) and shows that the appreciation of the real exchange rate has a positive effect on credit risk. So, overall, the effect of exchange rate on NPLs may be in both directions.

Finally, public debt is also viewed to be a crucial determinant of NPLs. The linkage between public debt and NPLs was particularly acknowledged after the global financial crisis. In fact, Louzis et al. (2012) postulate the sovereign debt hypothesis, which asserts that rising sovereign debt increases NPLs. Makri et al. (2014) also report strong correlations between NPLs and sovereign debt in the euro area and highlight that fiscal problems in these countries may raise impaired loans.

\subsection{Feedback Effects}

Many studies analyze feedback effects between the banking sector and economic performance using a panel VAR approach. In these models, the impact of the real economy on NPLs is largely accounted for by weakening borrower's capacity to repay the loan. Meanwhile, NPLs are assumed to affect the real economy mostly through the credit supply channel. In most of these studies, single or cross-country 
data are used in conjunction with aggregate or bank-level data. For example, Love and Ariss (2014) investigate feedback effects between NPLs and macroeconomic and bank-specific variables using bank-level data for Egypt. Likewise, Belgrave et al. (2012) explore feedback effects for NPLs for Barbados also using data on individual banks. On the other hand, Nkusu (2011) and Klein (2013) analyze feedback effects by aggregate and cross-country data. Meanwhile, Beaton et al. (2016) and Espinoza and Prasad (2010) examine feedback effects using cross-country bank-level data. Overall, these studies all document the significance of feedback effects between NPLs, bank-specific variables and macroeconomic variables.

\section{Econometric Methodology, Data Selection and Empirical Results}

\subsection{Econometric Methodology}

In line with the above discussion, the analysis applies a panel VAR methodology to assess the magnitude and duration of feedback effects. The technique is useful as it combines the traditional VAR approach, which treats all the variables in the system as endogenous, with a panel data approach, which allows for unobserved individual heterogeneity. The technique is also beneficial as it does not require any a priori assumptions about the direction of the feedback between variables. Hence, in the spirit of Klein (2013), Nkusu (2011), Belgrave et al. (2012), Beaton et al. (2016) and Espinoza and Prasad (2010), a panel VAR model can be estimated as follows:

$$
Y_{i t}=A_{1}(L) Y_{i t}+A_{2}(L) W_{t}+U_{i t}
$$

Where $Y_{i t}$ is a vector of endogenous variables that are composed of bank-specific and macroeconomic variables; $W_{t}$ is a vector of predetermined or exogenous variables; $A_{1}(L)$ and $A_{2}(L)$ are lag operators; and $U_{i t}$ is a vector of random disturbances. Clearly, $i$ denotes each bank and $t$ represents time.

\subsection{Data Selection}

The database covers an unbalanced panel of 31 deposit banks between 2002Q42017Q4, which is composed of 1891 observations. Bank-specific determinants and macroeconomic variables are selected in line with the above discussion. Hence, NPL is the dependent variable, while bank-specific independent variables are capital adequacy, lending, profitability, efficiency and bank size, whereas macroeconomic variables are inflation, GDP, policy rate, exchange rate, unemployment and debt stock. Table A1 presents the data source and description, while Table A2 presents the correlation matrix. 


\subsection{Empirical Results for the Benchmark Model}

This section explores feedback effects between banking sector and the real economy for the overall sample. The dynamic behavior of the model is assessed using impulse-response functions, which describe the reaction of one variable in the system to innovations in another variable in the system while holding all other shocks at zero. All shocks are orthogonalized using Cholesky decomposition. This implies that variables appearing earlier in the ordering are considered more exogenous, while those appearing later are considered more endogenous. In this context, it is more likely that the macroeconomic shocks are transmitted to banks' balance sheets than the bank-specific shocks to be transmitted to macroeconomic aggregates. Hence, macroeconomic variables appear earlier in the ordering.

In the next step, the stationarity property of the series is investigated. This can be performed using a variety of tests. In particular, Levin et al. (2002), Harris and Tzavalis (1999), Breitung (2002), Breitung and Das (2005), Im et al. (2003), and Fisher-type Choi (2001) tests analyze stationarity of a panel data by the null hypothesis that all the panels contain a unit root against the alternative hypothesis that at least one panel is stationary. In addition, the Lagrange multiplier (LM) test proposed by Hadri (2000) can also be used to investigate stationarity in panel data. Except for Fisher-type tests, all the remaining tests require balanced panels. Given that our panel is unbalanced, the stationarity of the series is tested using Fisher-ADF and Fisher-PP tests ${ }^{3}$, which allow for data gaps. The test results in Table A3 suggest that all bank-specific and macroeconomic variables are stationary.

In the following step, the panel VAR model is estimated. ${ }^{4}$ The number of lags is determined based on the selection criteria ${ }^{5}$ in Table A4 and the stability test results ${ }^{6}$ of the estimated models. Mindful of the limited degrees of freedom associated with the relatively short time span of the data, variables enter with two lags and using

3 The Fisher test combines p-values from the panel-specific unit-root tests proposed by Maddala and Wu (1999) and Choi (2001).ADF and PP stand for Augmented Dickey-Fuller and Phillips-Perron(Dickey and Fuller, 1979; Phillips and Perron, 1988).

4 The panel VAR is computed using the application written by Love and Zicchino (2006) in STATA using generalized method of moments (GMM) estimator. Our VAR model is based on system GMM approach of Arellano and Bover (1995) and Blundell and Bond (1998), which uses forward orthogonal deviation to overcome the low precision problem in samples with a limited time dimension.

5 Andrews and Lu (2001)proposed consistent moment and model selection criteria for GMMmodels based on Hansen's J-statistic (Hansen, 1982) of over-identifying restrictions. Their proposed model selection criteria are analogous to various commonly used maximum likelihood model selection criteria, namely theAkaikeinformation criteria(Akaike, 1969), the Bayesian-Schwarz information criteria(Schwarz, 1978), and the Hannan-Quinn information criteria(Hannan and Quinn, 1979), respectively.

6 Stability implies that the panel VAR is invertible and has an infinite-order vector moving-average representation. The condition is satisfied if all moduli of the companion matrix are strictly less than one as shown by Lütkepohl (2005) and Hamilton (1994). 
the first three lags of the dependent variables as instruments. The Wald test for Granger causality shows that one can reject the null hypothesis that the excluded variable does not Granger cause the equation variable. Standard errors are assumed to be robust to avoid any misspecification.

In the next step, we analyze how NPL responds to impulses in bank-specific and macroeconomic variables. Figure A1 shows that shocks to capital adequacy and profitability lead to a significant drop in NPL, while impulses in lending and efficiency cause an increase in NPL. These responses are all plausible as discussed earlier. In particular, the negative link between capital adequacy and NPL is attributed to the fact that higher capital makes banks less willing to grant high risk loans, which causes lower NPLs. Also, the negative response of NPLs to profitability impulse is because more profitable banks are believed to have higher quality assets that generates lower NPLs. The positive response of NPL to lending shock is plausible as well since NPLs are expected to rise in case of higher lending. Moreover, the positive response of NPL to efficiency impulse is linked to the skimping hypothesis, which predicts that higher efficiency may cause less screening for credits, leading to higher unpaid loans. Meanwhile, the response of NPL to a bank size shock is insignificant.

As for macroeconomic shocks, the initial responses of NPL are all insignificant, except for the policy rate shock to which NPL responds negatively. This is somewhat unexpected since higher policy rates are expected to increase market rates, and this may induce bad loans. Also, the response of NPL to impulses in inflation and exchange rate is positive and significant at the second quarter. These responses seem reasonable as higher inflation and less valuable Turkish lira reduce the repayment capacity of the borrower. The response of NPL to an NPL shock is positive and dies out afterwards as expected.

In the following step, the orthogonalized impulse-responses of bank-specific and macroeconomic variables to one-unit standard shock in NPL are analyzed. This part should be treated cautiously as the literature is more interested in finding out how NPLs react to shocks in explanatory variables rather than exploring how these explanatory variables react to an NPL shock. This is because the implications for the latter are somewhat trivial. In other words, an increase in bad loans is an adverse development, which clearly has an unfavorable impact on banks' balance sheet and macroeconomic variables. Against this background, Figure A2 shows that an increase in NPL has a positive effect on capital adequacy and a negative effect on bank size, while responses of other bank-specific variables are insignificant. As for 
macroeconomic variables, the NPL impulse has a significant effect on only inflation, which is positive. Overall, the responses seem reasonable with expected signs.

In the next step, the forecast error variance decomposition is computed, based on a Cholesky decomposition of the residual covariance matrix of the panel VAR model. This helps to assess the extent to which the forecast error variance of one variable is associated with shocks to other variables. The results in Table A5 indicate that at shorter horizons, the forecast error variance in NPL mostly stems from shocks to NPL itself. However, the weight of bank-specific and macroeconomic variables increases over time. This implies that the future uncertainty of NPL is likely to be fed more by future shocks in other variables over longer horizons. To be specific, the weight of NPL is around 95.8 percent in the first quarter, while that of bank-specific variables and macroeconomic variables is 3.6 and 0.5 percent, respectively. Yet, the weight of NPL decreases to 58.2, while that of bank-specific variables and macroeconomic variables increases to 33.8 and 8.1 percent by the end of the 12th quarter.

In the last step, the forecast error variance decomposition of bank-specific variables and macroeconomic variables is analyzed. Table A6 displays that NPL has a relatively higher weight in the forecast error variance decomposition of bank-specific variables compared to macroeconomic variables. Also, the weight of NPL increases over time in explaining the future uncertainty in these variables. Specifically, in cumulative terms, NPL provides the highest contribution to capital adequacy (by 85.6 percent) among bank-specific variables and to inflation (by 21.6 percent) among macroeconomic variables by the end of the 12 th quarter.

\subsection{Robustness Check}

In this section, the previous analysis is repeated by sub-periods as a robustness check. The overall sample is divided between the pre-crisis period (2002Q4-2008Q4) and the post-crisis period (2009Q1-2017Q4), which contains 775 and 1116 observations, respectively. Accordingly, Table A7 shows that all bank-specific variables are integrated of order one in both sub-samples, while inflation and policy rate are stationary in the pre-crisis period, whereas GDP and exchange rate are stationary in the post-crisis period. Other variables are non-stationary and transformed by logdifferencing to solve the non-stationarity problem.

Next, the panel VAR model is estimated, and the lag number is determined based on the selection criteria and the stability test results in Table A8. Accordingly, variables enter with one lag and using the first two lags of the dependent variables 
as instruments for the pre-crisis period, and variables enter with one lag using the first four lags of the dependent variables as instruments for the post-crisis period based on the information criteria tests. Also, the Wald test for Granger causality shows that one can reject the null hypothesis that the excluded variable does not Granger cause the equation variable for both sub-periods. Standard errors are assumed to be robust as in the benchmark model.

In the next step, the impulse-responses are analyzed. Figures A3-A4 show how NPL responds to shocks in bank-specific and macroeconomic variables for the precrisis and the post-crisis periods, respectively. ${ }^{7}$ The analysis produces different results for the two sub-samples, which implies that the feedback effects have changed after the crisis.

Accordingly, Figure A3 shows how NPL responds to impulses in bank-specific and macroeconomic variables in the pre-crisis period. Accordingly, as in the benchmark model, NPL responds positiv ely to efficiency and lending, and negatively to profitability. Also, NPL responds negatively to capital adequacy but not instantaneously unlike the benchmark model. Moreover, bank size impulse produces a significant and positive response in NPL in the second quarter differently from the benchmark model, which generates no significant response. This positive link can be attributed to the fact that larger banks are more likely to take higher risk by granting loans even to lower quality borrowers as discussed earlier.

As for macroeconomic impulses, NPL responds positively to shocks in inflation as in the benchmark model. In the second quarter, NPL responds also positively to exchange rate impulse as in the benchmark model. However, unlike the benchmark model, NPL responds significantly to the unemployment shock and the response is positive. This is plausible since higher unemployment has a trivial adverse effect on the debt servicing ability of the borrower as discussed earlier in the paper. Also, unlike the benchmark model, the response of NPL to a debt stock shock is significantly positive in the first quarter. This is also plausible since rising sovereign debt increases NPLs in line with the sovereign debt hypothesis as discussed earlier. Also, the response of NPL to a growth shock is significant unlike the benchmark model, and the response is negative in the second quarter. On the other hand, the response of NPL to the policy rate impulse is insignificant unlike the benchmark model. In the meantime, the impulse-response of NPL to an NPL shock is plausible as the initial response is positive. All the responses die out over the longer horizon.

7 The responses of bank-specific and macroeconomic variables to NPL shocks and the variance decomposition analyses are not reported for simplicity, but available upon request. 
As for the post-crisis period, Figure A4 displays that feedback effects between NPL and bank-specific variables are different than those in the pre-crisis period. More specifically, unlike the pre-crisis period where NPL shows no immediate significant response to capital adequacy, the capital adequacy impulse produces an instantaneous significant and negative response in NPL in the post-crisis period as in the benchmark model. Also, NPL responds positively to profitability in the post-crisis period, whereas its response is negative in the pre-crisis period and in the benchmark model. This positive link can be explained by the bad management II hypothesis, which posits that lower profitability is associated with higher NPLs as explained earlier.

In addition, unlike the pre-crisis period and the benchmark model, the response of NPL to a lending shock is insignificant in the post-crisis period. Moreover, the response of NPL to the bank size impulse is significant yet negative unlike the precrisis period and the benchmark model. This adverse relation can be attributed to the diversification hypothesis. This postulates that larger banks have better chances of diversification, which enables them to lower their risk. On the other hand, NPL responds positively to an efficiency shock in the post-crisis period similar to the precrisis period and also the benchmark model, validating the skimping hypothesis.

As for the feedback effects between NPL and the macroeconomic variables, the dynamics are also different after the global crisis compared to those in the pre-crisis case and the benchmark model. In particular, unlike the pre-crisis period where the immediate response of NPL to a GDP shock is insignificant, NPL responds significantly to GDP, and the response is negative confirming the countercyclical behavior of bad loans as discussed previously. In addition, unlike the pre-crisis period which yields an insignificant immediate response of NPL to a debt stock impulse, the response of NPL is significant instantaneously in the positive direction in the postcrisis period. In addition, unlike the pre-crisis period and the benchmark model, the response of NPL to an exchange rate shock is insignificant. Meanwhile, similar to the benchmark model but unlike the pre-crisis period, NPL responds significantly to the policy rate shock, and the response is negative. On the other hand, NPL responds positively to an inflation impulse after the global crisis similar to the pre-crisis period and the benchmark model. Moreover, the response of NPL to an unemployment shock is also positive in the post-crisis period as in the pre-crisis period. Meanwhile, the impulse-response of NPL to NPL shock itself is positive as expected. 


\section{Discussion of the Results}

The panel VAR analysis for the robustness check is useful as the results are mostly dissimilar between the two sub-periods. In addition, the results also differ with respect to the benchmark model. This outcome is in line with the previous findings reported for the Turkish economy by Us (2016, 2017, 2018), which argue that the global crisis changed the dynamics of NPLs in the Turkish banking sector. Given the importance of NPLs as a leading indicator for accumulated financial risks in the economy, it is crucial to thoroughly understand the NPL dynamics, which have distinctive characteristics in each sub-period.

In particular, the estimations conducted by sub-periods produce more significant responses compared to the benchmark model. In addition, the estimations produce more significant responses for the post-crisis period compared to other estimations. This is especially true for macroeconomic variables. This confirms findings by Ganioğlu and Us (2014) and Us (2018), which assert that the Turkish banking sector is more sensitive to macroeconomic conditions in the post-crisis period. In addition, these responses are more persistent in the post-crisis period compared to more immediate responses in the benchmark model and the pre-crisis period estimations that die out quickly.

On the other hand, one crucial point to be mentioned is the fact that some variables play an important role in NPL dynamics regardless of whether the analysis covers the overall data span or only the pre-crisis or post-crisis periods. In this respect, profitability, efficiency and capital adequacy feature out as the most important bankspecific variables in terms of credit risk since their impulses produce significant and plausible responses in NPLs in all cases. In other words, the good management of banks, which can be measured by higher profitability and efficiency seems to matter the most for loan quality in both the pre-crisis and the post-crisis periods and in the overall sample. Also, increased regulatory capital tends to improve credit risk and reduces NPLs.

Lending is also important as NPL responds to lending shocks in both the benchmark model and the pre-crisis period. Hence, it can be concluded that excessive risk-taking measured by higher lending worsens loan quality and leads to higher NPLs. Meanwhile, bank size is also important in NPL dynamics since NPL responds to a bank size shock in both sub-periods. Yet, the direction of the effect changes sign between the two sub-periods, thereby causing its impulse to be insignificant for NPL dynamics in the overall data. 
A similar conclusion can be drawn for macroeconomic variables. In this context, inflation is the most important variable to which NPL responds in all settings. GDP growth, unemployment and debt stock are also important since their shocks produce significant responses in NPL in both the pre-crisis and the post-crisis periods. On the other hand, exchange rate seems to matter only in the pre-crisis period and in the benchmark model. A similar observation applies to policy rate, the impulse of which produces significant response only in the post-crisis period and in the benchmark model.

As a policy implication, these results indicate that prudential policies targeting capital adequacy and lending are expected to have favorable effects on credit risk. Also, measures to increase the effective functioning of banks, and therefore, improve their profitability and efficiency have also positive implications for credit risk. In this regard, proactive policies may be needed to increase supervision, avoid excessive lending, maintain high credit standards and remove any regulatory impediments that pose downward pressure on banks' profitability. In addition, the results imply that macroeconomic policies opting for lower inflation also lowers credit risk. Yet, these policies should also be associated with strong economic growth and higher employment as well as sustainable fiscal balances for reducing credit risk.

\section{Concluding Remarks}

This paper examines the determinants of NPLs in the Turkish banking sector by panel VAR approach using bank-level data for the period between 2002Q4 and 2017Q4. The selected determinants are composed of major bank-level indicators, such as capital adequacy, profitability and lending, which have previously been reported to affect NPL dynamics. The set of determinants also includes important macroeconomic variables such as inflation and growth, which have been treated as relevant factors in earlier studies for NPL dynamics.

The traditional VAR methodology is used to capture the linear interdependencies among multiple time series. Likewise, the panel VAR approach is utilized to assess the presence of multidirectional relations but this time using panel data. In this case, the approach is preferred as it helps to analyze feedback effects in NPLs. For the Turkish economy case, the panel VAR model is applied given the previous evidence for other countries that NPLs are responsive to various shocks either originating from bank-specific or macroeconomic factors, and these factors may also respond to shocks in NPLs. In this context, this exercise is deemed necessary as it is the first formal attempt, at least to our knowledge, to analyze these linkages for the 
Turkish economy using panel VAR methodology. In addition, against some prior evidence that NPL dynamics have changed after the global crisis, the paper conducts a robustness check analyzing the impulse-responses of NPLs by sub-periods.

Overall, the panel VAR confirms the existence of strong feedback effects among the selected variables. Also, the analysis by sub-periods in the alternative model for the robustness check verifies the changing dynamics of NPLs by producing more significant responses compared to the benchmark model. In addition, more meaningful responses are produced and NPLs have higher sensitivity to macroeconomic conditions in the post-crisis period. Despite the evidence for changing dynamics, capital adequacy, profitability and efficiency still feature as the most important bank-specific variables, the impulses of which produce significant and plausible responses in NPLs in all cases. Similarly, NPLs respond reasonably to shocks in fundamental macroeconomic indicators like inflation, GDP growth, unemployment and debt stock. In this regard, the impulse-response functions reveal that a positive shock to growth leads to the reduction of NPLs while higher inflation, unemployment and debt stock cause higher NPLs as expected.

For the refinement of these results, future studies may be conducted separately for each loan category. This may enable to directly identify the loan type that is likely to generate NPLs. In addition, prospective studies may also take into account the role of global financial conditions. Similarly, further research can be extended by an ownership breakdown. This may facilitate to recognize structural factors inducing NPLs distinctive to each ownership category. Also, other ownership-specific variables may be added to better capture bank characteristics. Finally, a thorough understanding of the underlying structural forces driving the NPLS is also crucial, which, however, is beyond the scope of this paper. 
Appendix

Table A1. Description of Variables

\begin{tabular}{|l|l|l|}
\hline Variables & Description & Source \\
\hline Bank-Specific Variables & & \\
\hline NPL & Non-performing loans to total loans & https://www.tbb.org.tr \\
\hline Capital adequacy & Shareholders' equity to risk-weighted assets & https://www.tbb.org.tr/ \\
\hline Lending & Total loans and receivables to total assets & https://www.tbb.org.tr/ \\
\hline Profitability & Net profits (loss) to total assets & https://www.tbb.org.tr/ \\
\hline Efficiency & Total operating income to other operating expenses & https://www.tbb.org.tr/ \\
\hline Bank size & Total assets to GDP & https://www.tbb.org.tr/ \\
\hline Macroeconomic Variables & & \\
\hline Inflation & Year-on-year change in the consumer price index in logs & http://www.tuik.gov.tr/ \\
\hline GDP & Year-on-year change in the real GDP in logs & http://www.tuik.gov.tr/ \\
\hline Policy rate & CBRT policy rate & https://evds2.tcmb.gov.tr/ \\
\hline Exchange rate & Quarter-on-quarter change in USD/TL rate in logs & https://evds2.tcmb.gov.tr/ \\
\hline Unemployment & Unemployment rate (seasonally adjusted) & http://www.tuik.gov.tr/ \\
\hline Debt stock & Central government domestic debt stock to GDP & https://www.hmb.gov.tr/ \\
\hline
\end{tabular}

Table A2. Correlation Matrix

\begin{tabular}{|c|c|c|c|c|c|c|c|c|c|c|c|c|}
\hline & $\overrightarrow{\underline{n}}$ & $\begin{array}{l}\frac{\pi}{0} \\
\frac{0}{0} \\
\frac{d}{0} \\
\frac{0}{0} \\
\frac{0}{0} \\
\frac{0}{0} \\
\frac{0}{0}\end{array}$ & 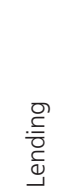 & 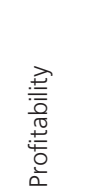 & 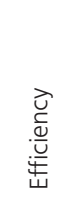 & $\begin{array}{l}\stackrel{\Xi}{N} \\
\frac{N}{N} \\
\frac{v}{D} \\
\infty\end{array}$ & 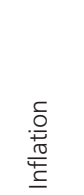 & 今े & $\begin{array}{l}\stackrel{\oplus}{0} \\
\stackrel{ \pm}{0} \\
\frac{.0}{0} \\
0\end{array}$ & 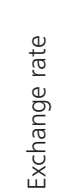 & 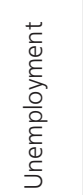 & 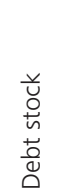 \\
\hline NPL & 1.000 & & & & & & & & & & & \\
\hline Capital adequacy & 0.217 & 1.000 & & & & & & & & & & \\
\hline Lending & 0.126 & 0.281 & 1.000 & & & & & & & & & \\
\hline Profitability & 0.053 & 0.242 & 0.217 & 1.000 & & & & & & & & \\
\hline Efficiency & -0.025 & -0.088 & -0.084 & -0.358 & 1.000 & & & & & & & \\
\hline Bank size & -0.099 & -0.206 & 0.202 & 0.060 & -0.281 & 1.000 & & & & & & \\
\hline Inflation & 0.103 & 0.101 & 0.105 & 0.151 & -0.040 & -0.035 & 1.000 & & & & & \\
\hline GDP & 0.032 & 0.012 & -0.025 & -0.033 & 0.010 & -0.002 & 0.120 & 1.000 & & & & \\
\hline Policy rate & 0.086 & 0.116 & 0.215 & 0.164 & -0.013 & -0.061 & 0.845 & 0.007 & 1.000 & & & \\
\hline Exchange rate & -0.001 & -0.018 & -0.206 & -0.051 & -0.085 & 0.050 & -0.043 & -0.296 & -0.207 & 1.000 & & \\
\hline Unemployment & 0.034 & 0.010 & -0.005 & 0.0351 & -0.039 & 0.016 & -0.068 & -0.563 & -0.073 & 0.340 & 1.000 & \\
\hline Debt stock & 0.060 & 0.082 & 0.375 & 0.141 & 0.014 & -0.060 & 0.431 & 0.021 & 0.674 & -0.467 & 0.004 & 1.000 \\
\hline
\end{tabular}


Table A3. Unit Root Tests for the Overall Sample

\begin{tabular}{|c|c|c|c|c|c|}
\hline \multicolumn{6}{|c|}{ Panel Unit Root Tests } \\
\hline Variable & Lag Number & $\begin{array}{l}\text { Fisher-ADF } \\
\text { Z-statistic }\end{array}$ & $\begin{array}{l}\text { Fisher-PP } \\
\text { Z-statistic }\end{array}$ & $\begin{array}{l}\text { Fisher-ADF } \\
\text { critical p-value }\end{array}$ & $\begin{array}{l}\text { Fisher-PP } \\
\text { critical p-value }\end{array}$ \\
\hline \multirow{3}{*}{ NPL } & 0 & -8.525 & -8.526 & 0.000 & 0.000 \\
\hline & 1 & -8.955 & -8.922 & 0.000 & 0.000 \\
\hline & 2 & -8.726 & -9.223 & 0.000 & 0.000 \\
\hline \multirow{3}{*}{ Capital adequacy } & 0 & -13.203 & -13.204 & 0.000 & 0.000 \\
\hline & 1 & -8.267 & -12.898 & 0.000 & 0.000 \\
\hline & 2 & -8.391 & -12.773 & 0.000 & 0.000 \\
\hline \multirow{3}{*}{ Lending } & 0 & -4.304 & -4.304 & 0.000 & 0.000 \\
\hline & 1 & -2.278 & -4.052 & 0.011 & 0.000 \\
\hline & 2 & -3.014 & -4.125 & 0.001 & 0.000 \\
\hline \multirow{3}{*}{ Profitability } & 0 & -22.630 & -22.630 & 0.000 & 0.000 \\
\hline & 1 & -9.995 & -22.569 & 0.000 & 0.000 \\
\hline & 2 & -11.024 & -22.700 & 0.000 & 0.000 \\
\hline \multirow{3}{*}{ Efficiency } & 0 & -8.572 & -8.572 & 0.000 & 0.000 \\
\hline & 1 & -8.443 & -8.559 & 0.000 & 0.000 \\
\hline & 2 & -6.020 & -8.567 & 0.000 & 0.000 \\
\hline \multirow{3}{*}{ Bank size } & 0 & -4.307 & -4.307 & 0.000 & 0.000 \\
\hline & 1 & -2.034 & -4.127 & 0.021 & 0.000 \\
\hline & 2 & 1.056 & -3.271 & 0.855 & 0.001 \\
\hline
\end{tabular}

Time Series Unit Root Tests

\begin{tabular}{|l|c|c|c|c|c|}
\hline & ADF statistic & PP statistic & $\begin{array}{l}\text { Critical p-value } \\
(1 \%)\end{array}$ & $\begin{array}{l}\text { Critical p-value } \\
(5 \%)\end{array}$ & $\begin{array}{l}\text { Critical p-value } \\
(10 \%)\end{array}$ \\
\hline Inflation & $-5.789^{*}$ & $-5.503^{*}$ & -3.566 & -2.922 & -2.596 \\
\hline GDP & $-3.028^{*}$ & $-3.298^{*}$ & -3.566 & -2.922 & -2.596 \\
\hline Policy rate & $-5.667^{*}$ & $-5.038^{*}$ & -3.566 & -2.922 & -2.596 \\
\hline Exchange rate & $-2.999^{*}$ & $-3.314^{* *}$ & -3.566 & -2.922 & -2.596 \\
\hline Unemployment & $-1.682^{* *}$ & $-2.262^{* *}$ & -2.392 & -1.672 & -1.296 \\
\hline Debt stock & $-3.265^{*}$ & $-2.715^{* * *}$ & -3.566 & -2.922 & -2.596 \\
\hline
\end{tabular}

Notes: ${ }^{*}{ }^{* *}$ and ${ }^{* * *}$ denote rejection of a unit root at 1,5 and 10 percent statistical significance, respectively. 
Table A4. Selection Criteria for the Benchmark Model

\begin{tabular}{|l|c|c|c|c|c|}
\hline Model & Stability & $\begin{array}{l}\text { Hansen's } \\
\text { J-statistics }\end{array}$ & MMSC-BIC & MMSC-AIC & MMSC-HQIC \\
\hline $\begin{array}{l}\text { First one instrument } \\
\text { with one lag }\end{array}$ & Yes & 1048.083 & 23.089 & 760.083 & 482.846 \\
\hline $\begin{array}{l}\text { First two instruments } \\
\text { with one lag }\end{array}$ & No & 814.479 & -206.852 & 526.479 & 250.273 \\
\hline $\begin{array}{l}\text { First three instruments } \\
\text { with one lag }\end{array}$ & Yes & 1105.461 & -929.682 & 529.461 & -20.8271 \\
\hline $\begin{array}{l}\text { First three instruments } \\
\text { with two lags }\end{array}$ & Yes & 777.964 & -239.607 & 489.964 & 214.820 \\
\hline $\begin{array}{l}\text { First four instruments } \\
\text { with one lag }\end{array}$ & No & 1137.148 & -1903.985 & 273.148 & -548.999 \\
\hline $\begin{array}{l}\text { First four instruments } \\
\text { with two lags }\end{array}$ & Yes & 1084.375 & -943.047 & 508.375 & -39.7234 \\
\hline $\begin{array}{l}\text { First four instruments } \\
\text { with three lags }\end{array}$ & Yes & 820.504 & -193.207 & 532.504 & 258.455 \\
\hline
\end{tabular}

Notes: MMSC stand for moment and model selection criteria and BIC, AIC and HQIC stand for Akaike information criteria, Bayesian-Schwarz information criteria and the Hannan-Quinn information criteria, respectively. Models which pass the stability criteria are shown in bold. Stability condition is satisfied if all the eigenvalues lie inside the unit circle. 
Figure A1. Impulse-Responses of NPL to Shocks in Bank-Specific and Macroeconomic Variables in the Benchmark Model

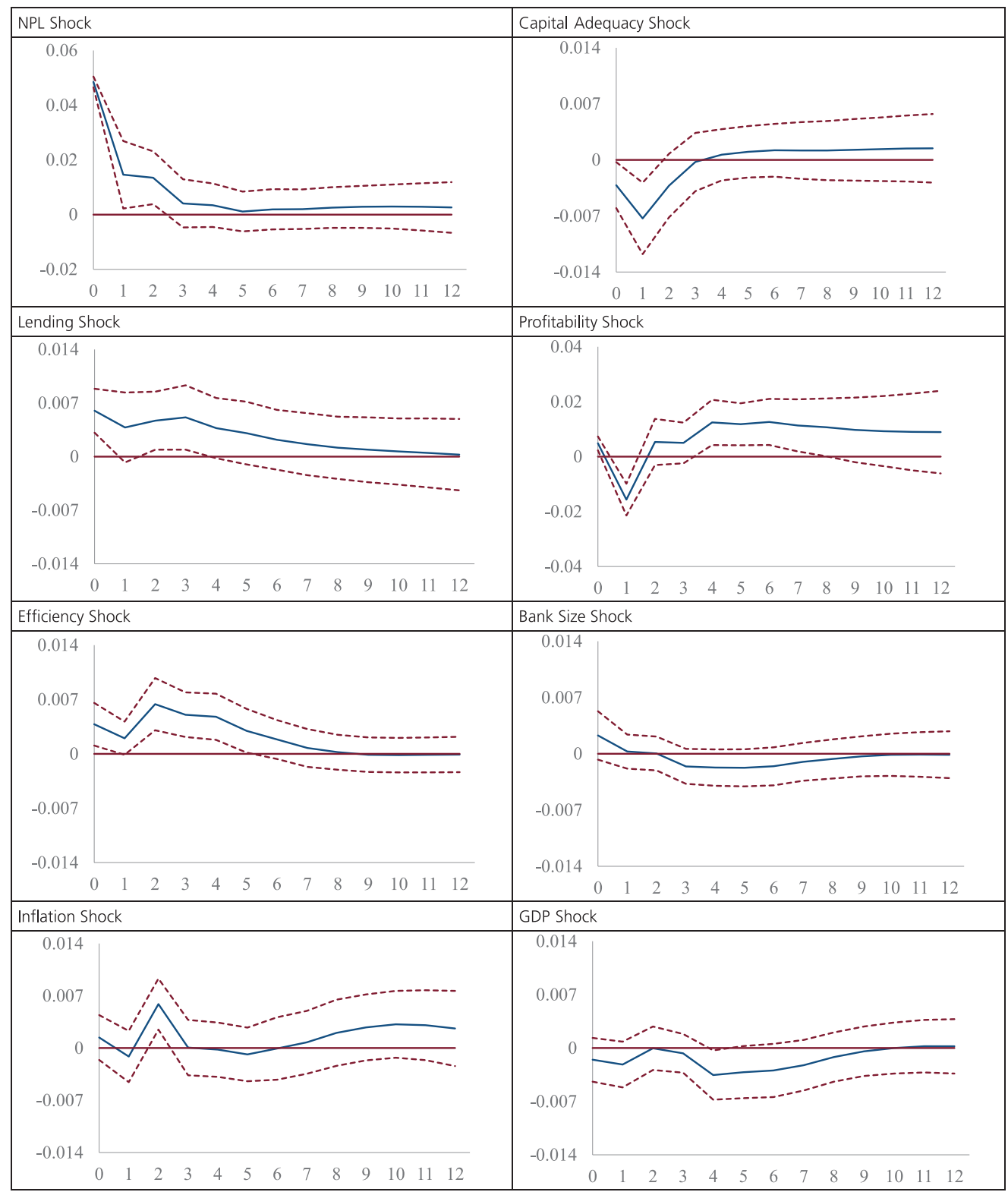


Figure A1. Impulse-Responses of NPL to Shocks in Bank-Specific and Macroeconomic Variables in the Benchmark Model (continued)

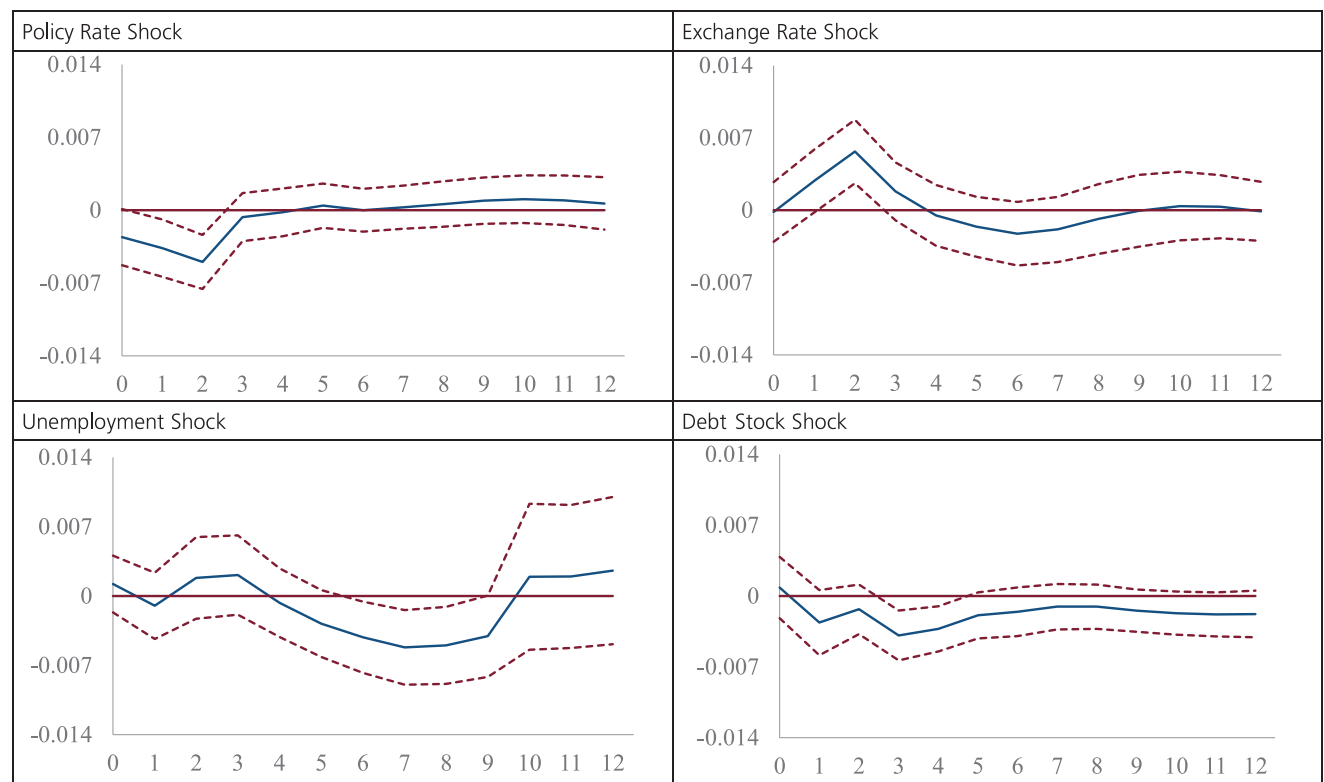

Notes: The blue line shows the impulse-response of NPL to one-unit standard shock in the respective variable over 12 quarters. The red dotted lines are the upper and lower bounds of the 95 percent confidence bands, which are based on Gaussian approximation of 200 Monte Carlo simulations. 
Figure A2. Impulse-Responses of Bank-Specific and Macroeconomic Variables to an NPL Shock in the Benchmark Model

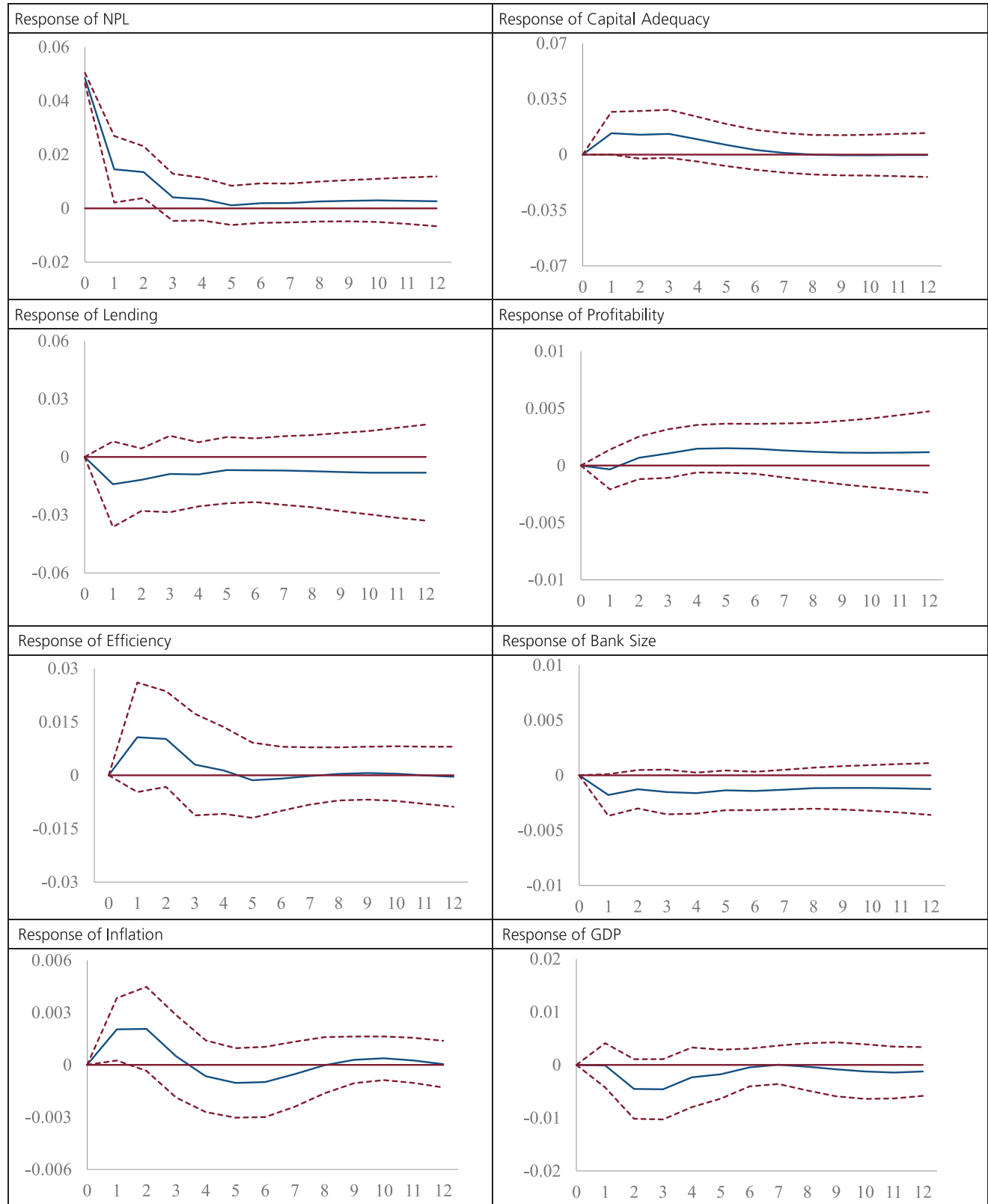


Figure A2. Impulse-Responses of Bank-Specific and Macroeconomic Variables to an NPL Shock in the Benchmark Model (continued)

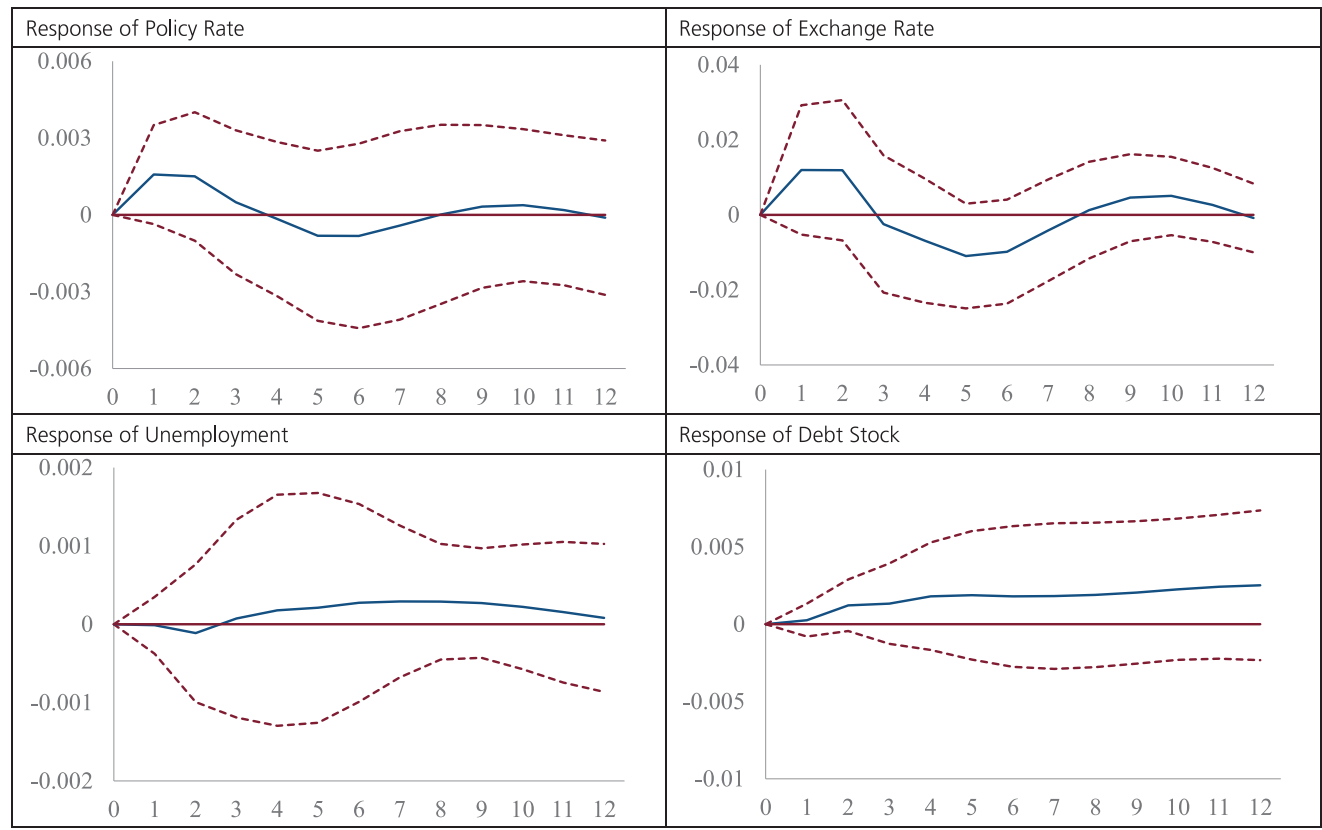

Notes: The blue line shows the impulse-response of NPL to one-unit standard shock in the respective variable over 12 quarters. The red dotted lines are the upper and lower bounds of the 95 percent confidence bands, which are based on Gaussian approximation of 200 Monte Carlo simulations.

Table A5. Forecast Error Variance Decomposition of NPL in the Benchmark Model

\begin{tabular}{|l|l|l|l|}
\hline Horizon & NPL & Bank-Specific Variables & Macroeconomic Variables \\
\hline 1 & 0.958 & 0.036 & 0.005 \\
\hline 2 & 0.850 & 0.135 & 0.016 \\
\hline 3 & 0.808 & 0.150 & 0.043 \\
\hline 4 & 0.785 & 0.167 & 0.048 \\
\hline 5 & 0.740 & 0.209 & 0.051 \\
\hline 6 & 0.705 & 0.240 & 0.055 \\
\hline 7 & 0.671 & 0.269 & 0.061 \\
\hline 8 & 0.644 & 0.290 & 0.067 \\
\hline 9 & 0.623 & 0.305 & 0.072 \\
\hline 10 & 0.607 & 0.317 & 0.076 \\
\hline 11 & 0.594 & 0.328 & 0.079 \\
\hline 12 & 0.582 & 0.338 & 0.081 \\
\hline
\end{tabular}


Table A6. The Effect of NPL in Explaining the Forecast Error Variance Decomposition of Bank-Specific and Macroeconomic Variables in the Benchmark Model

\begin{tabular}{|c|c|c|c|c|c|c|c|c|c|c|c|c|}
\hline Variables Horizon & 1 & 2 & 3 & 4 & 5 & 6 & 7 & 8 & 9 & 10 & 11 & 12 \\
\hline Capital adequacy & 0 & 0.038 & 0.059 & 0.079 & 0.087 & 0.089 & 0.088 & 0.086 & 0.085 & 0.084 & 0.083 & 0.082 \\
\hline Lending & 0 & 0.028 & 0.038 & 0.040 & 0.042 & 0.041 & 0.039 & 0.038 & 0.038 & 0.038 & 0.038 & 0.039 \\
\hline Profitability & 0 & 0.001 & 0.005 & 0.011 & 0.022 & 0.031 & 0.037 & 0.042 & 0.044 & 0.045 & 0.046 & 0.47 \\
\hline Efficiency & 0 & 0.020 & 0.032 & 0.030 & 0.029 & 0.028 & 0.027 & 0.027 & 0.027 & 0.026 & 0.026 & 0.026 \\
\hline Bank size & 0 & 0.007 & 0.008 & 0.011 & 0.014 & 0.016 & 0.018 & 0.019 & 0.020 & 0.021 & 0.022 & 0.023 \\
\hline Inflation & 0 & 0.015 & 0.023 & 0.021 & 0.019 & 0.019 & 0.020 & 0.020 & 0.020 & 0.020 & 0.019 & 0.019 \\
\hline GDP & 0 & 0.000 & 0.009 & 0.015 & 0.017 & 0.017 & 0.015 & 0.012 & 0.011 & 0.011 & 0.011 & 0.011 \\
\hline Policy rate & 0 & 0.007 & 0.010 & 0.008 & 0.006 & 0.005 & 0.005 & 0.005 & 0.005 & 0.005 & 0.005 & 0.005 \\
\hline Exchange rate & 0 & 0.006 & 0.008 & 0.008 & 0.009 & 0.010 & 0.011 & 0.010 & 0.010 & 0.010 & 0.010 & 0.010 \\
\hline Unemployment & 0 & 0.000 & 0.000 & 0.000 & 0.000 & 0.001 & 0.001 & 0.001 & 0.002 & 0.002 & 0.002 & 0.002 \\
\hline Debt stock & 0 & 0.000 & 0.004 & 0.005 & 0.006 & 0.007 & 0.008 & 0.009 & 0.009 & 0.011 & 0.012 & 0.014 \\
\hline
\end{tabular}


Table A7. Unit Root Tests for the Robustness Check

\begin{tabular}{|c|c|c|c|c|c|}
\hline \multicolumn{6}{|c|}{ Panel Unit Root Tests (Pre-Crisis Period) } \\
\hline Variable & Lag Number & $\begin{array}{l}\text { Fisher-ADF } \\
\text { Z-statistic }\end{array}$ & $\begin{array}{l}\text { Fisher-PP } \\
\text { Z-statistic }\end{array}$ & $\begin{array}{c}\text { Fisher-ADF } \\
\text { critical p-value }\end{array}$ & $\begin{array}{c}\text { Fisher-PP } \\
\text { critical p-value }\end{array}$ \\
\hline \multirow{3}{*}{ NPL } & 0 & -6.349 & -6.349 & 0.000 & 0.000 \\
\hline & 1 & -7.795 & -6.827 & 0.000 & 0.000 \\
\hline & 2 & -6.949 & -7.120 & 0.000 & 0.000 \\
\hline \multirow{3}{*}{ Capital adequacy } & 0 & -6.297 & -6.297 & 0.000 & 0.000 \\
\hline & 1 & -5.343 & -6.297 & 0.000 & 0.000 \\
\hline & 2 & -6.602 & -6.163 & 0.000 & 0.000 \\
\hline \multirow{3}{*}{ Lending } & 0 & -3.015 & -3.015 & 0.000 & 0.000 \\
\hline & 1 & -1.861 & -2.871 & 0.000 & 0.000 \\
\hline & 2 & -2.092 & -2.941 & 0.018 & 0.002 \\
\hline \multirow{3}{*}{ Profitability } & 0 & -17.739 & -17.739 & 0.000 & 0.000 \\
\hline & 1 & -6.858 & -17.729 & 0.000 & 0.000 \\
\hline & 2 & 7.728 & -17.985 & 0.000 & 0.000 \\
\hline \multirow{3}{*}{ Efficiency } & 0 & -6.818 & -6.818 & 0.000 & 0.000 \\
\hline & 1 & -5.361 & -7.147 & 0.000 & 0.000 \\
\hline & 2 & -1.777 & -7.223 & 0.038 & 0.000 \\
\hline \multirow{3}{*}{ Bank size } & 0 & -1.978 & -1.978 & 0.000 & 0.000 \\
\hline & 1 & -0.821 & -1.948 & 0.206 & 0.026 \\
\hline & 2 & 3.911 & -0.808 & 1.000 & 0.210 \\
\hline \multicolumn{6}{|c|}{ Panel Unit Root Tests (Post-Crisis Period) } \\
\hline \multirow{3}{*}{ NPL } & 0 & -1.124 & -1.124 & 0.131 & 0.131 \\
\hline & 1 & -2.252 & -1.599 & 0.012 & 0.055 \\
\hline & 2 & -4.397 & -1.764 & 0.000 & 0.039 \\
\hline \multirow{3}{*}{ Capital adequacy } & 0 & -6.884 & -6.884 & 0.000 & 0.000 \\
\hline & 1 & -1.785 & -6.690 & 0.037 & 0.000 \\
\hline & 2 & -0.533 & -6.630 & 0.297 & 0.000 \\
\hline \multirow{3}{*}{ Lending } & 0 & -3.122 & -3.122 & 0.001 & 0.001 \\
\hline & 1 & -1.329 & -2.972 & 0.092 & 0.002 \\
\hline & 2 & -1.462 & -3.225 & 0.072 & 0.001 \\
\hline \multirow{3}{*}{ Profitability } & 0 & -5.389 & -5.389 & 0.000 & 0.000 \\
\hline & 1 & -6.130 & -5.930 & 0.000 & 0.000 \\
\hline & 2 & -6.768 & -6.254 & 0.000 & 0.000 \\
\hline \multirow{3}{*}{ Efficiency } & 0 & -4.630 & -4.630 & 0.000 & 0.000 \\
\hline & 1 & -6.561 & -4.776 & 0.000 & 0.000 \\
\hline & 2 & -5.267 & -4.815 & 0.000 & 0.000 \\
\hline \multirow{3}{*}{ Bank size } & 0 & -6.392 & -6.392 & 0.000 & 0.000 \\
\hline & 1 & -4.723 & -6.285 & 0.000 & 0.000 \\
\hline & 2 & -2.126 & -6.045 & 0.017 & 0.000 \\
\hline \multicolumn{6}{|c|}{ Time Series Root Tests (Pre-Crisis Period) } \\
\hline & ADF statistic & PP statistic & $\begin{array}{c}\text { Critical p-value } \\
(1 \%)\end{array}$ & $\begin{array}{c}\text { Critical p-value } \\
(5 \%)\end{array}$ & $\begin{array}{c}\text { Critical p-value } \\
(10 \%)\end{array}$ \\
\hline Inflation & $-4.261^{*}$ & $-3.708^{* *}$ & -3.750 & -3.000 & -2.630 \\
\hline GDP & -0.852 & -0.911 & -3.750 & -3.000 & -2.630 \\
\hline Policy rate & $-4.180^{*}$ & $-3.790^{\star}$ & -3.750 & -3.000 & -2.630 \\
\hline Exchange rate & -2.052 & -2.248 & -3.750 & -3.000 & -2.630 \\
\hline Unemployment & -1.248 & -1.331 & -3.750 & -3.000 & -2.630 \\
\hline Debt stock & -1.491 & -1.693 & -3.750 & -3.000 & -2.630 \\
\hline
\end{tabular}




\begin{tabular}{|l|c|c|c|c|c|}
\hline \multicolumn{7}{|l|}{ Time Series Root Tests (Post-Crisis Period) } \\
\hline Inflation & -2.178 & -2.382 & -3.682 & -2.972 & -2.618 \\
\hline GDP & $-5.135^{*}$ & $-5.004^{*}$ & -3.682 & -2.972 & -2.618 \\
\hline Policy rate & -2.096 & -2.517 & -3.682 & -2.972 & -2.618 \\
\hline Exchange rate & $-3.123^{\star *}$ & $-3.282^{* *}$ & -3.682 & -2.972 & -2.618 \\
\hline Unemployment & -1.902 & -1.953 & -3.682 & -2.972 & -2.618 \\
\hline Debt stock & -1.495 & -1.280 & -3.682 & -2.972 & -2.618 \\
\hline
\end{tabular}

Notes: ${ }^{*}{ }^{* *}$ and ${ }^{* * *}$ denote rejection of a unit root at 1,5 and 10 percent statistical significance, respectively.

Table A8. Selection Criteria for the Robustness Test

\begin{tabular}{|l|c|c|c|c|c|}
\hline \multicolumn{1}{|c|}{ Mre-crisis period } & Stability & $\begin{array}{c}\text { Hansen's } \\
\text { J-statistics }\end{array}$ & MMSC-BIC & MMSC-AIC & $\begin{array}{c}\text { MMSC- } \\
\text { HQIC }\end{array}$ \\
\hline First one instrument with one lag & No & 401.448 & -471.402 & 113.448 & -117.513 \\
\hline First two instruments with one lag & Yes & 337.748 & -519.145 & 49.748 & -175.900 \\
\hline First three instruments with one lag & No & 311.725 & -824.345 & -78.275 & -375.584 \\
\hline First four instruments with one lag & No & 351.758 & -409.367 & -70.458 & -369.347 \\
\hline Post-crisis period & & & & & \\
\hline First one instrument with one lag & Yes & 583.199 & -349.041 & 295.199 & 45.280 \\
\hline First two instruments with one lag & Yes & 622.215 & -1232.318 & 46.215 & -450.543 \\
\hline First three instruments with one lag & Yes & 603.607 & -2162.737 & -260.393 & -1000.716 \\
\hline First four instruments with one lag & Yes & 580.926 & -2207.588 & -295.074 & -1040.590 \\
\hline
\end{tabular}

Notes: MMSC stand for moment and model selection criteria and BIC, AIC and HQIC stand for Akaike information criteria, Bayesian-Schwarz information criteria and the Hannan-Quinn information criteria, respectively. Models which pass the stability criteria are shown in bold. Stability condition is satisfied if all the eigenvalues lie inside the unit circle. 
Figure A3. Impulse-Responses of NPL to Shocks in Bank-Specific and Macroeconoic Variables in the Alternative Model (pre-crisis period)

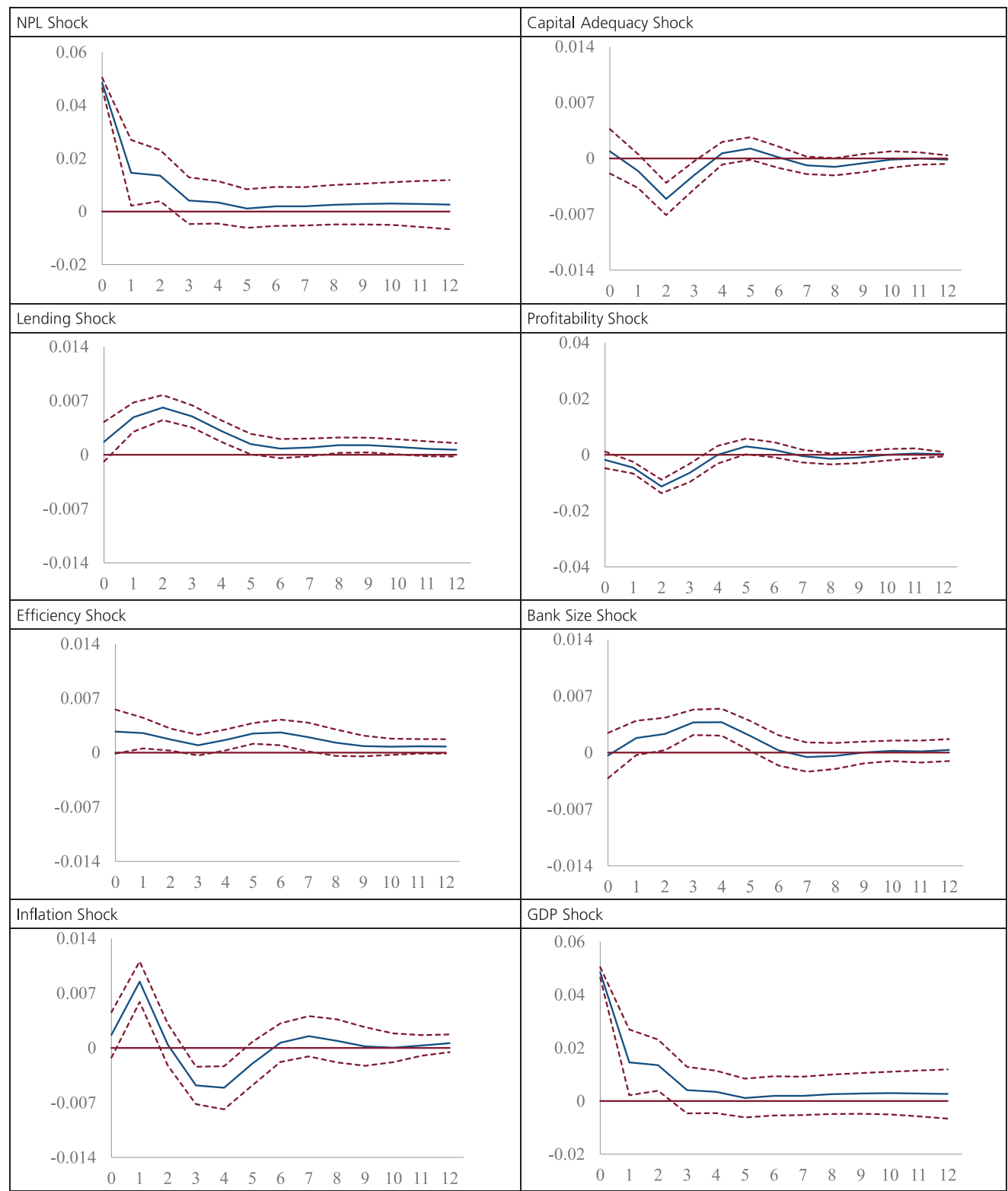


Figure A3. Impulse-Responses of NPL to Shocks in Bank-Specific and Macroeconomic Variables in the Alternative Model (pre-crisis period, continued)

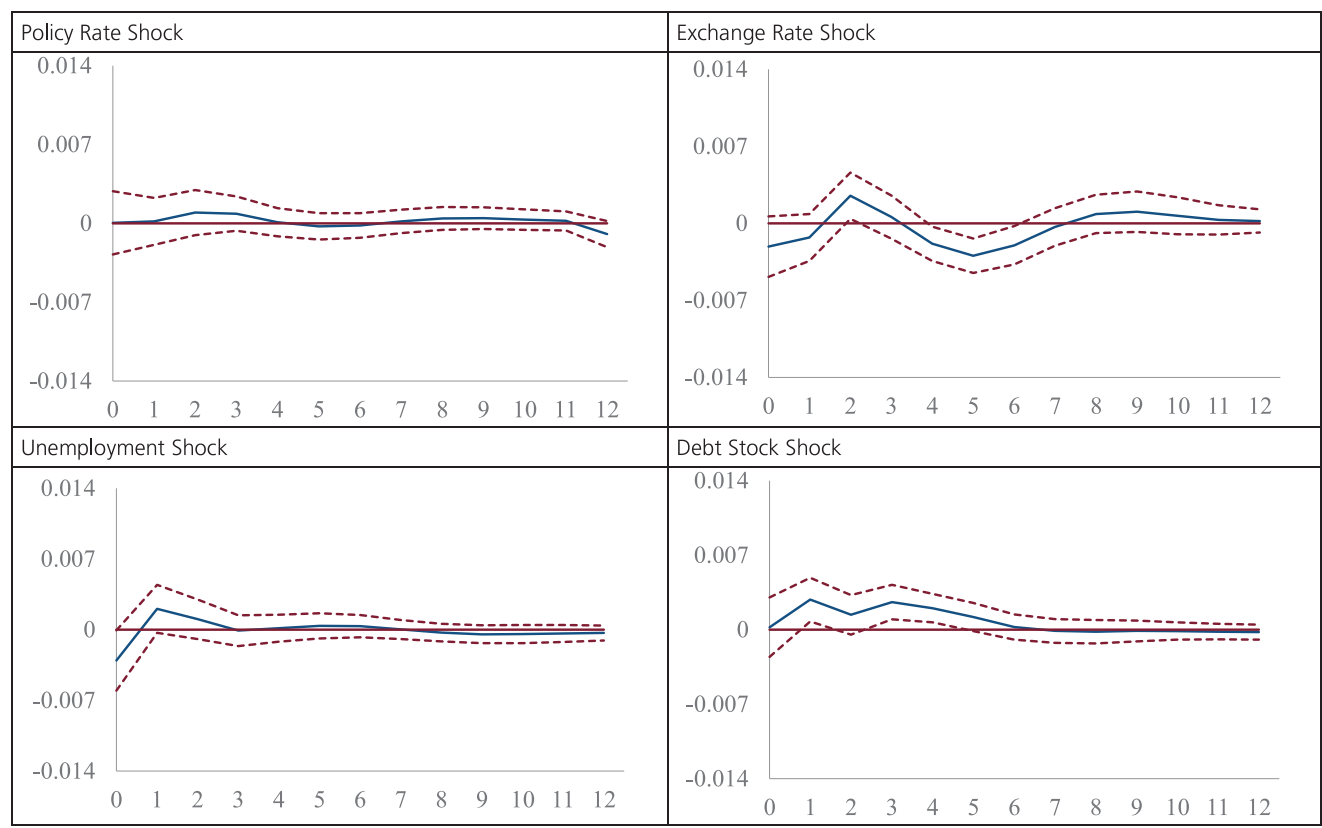

Notes: The blue line shows the impulse-response of NPL to one-unit standard shock in the respective variable over 12 quarters. The red dotted lines are the upper and lower bounds of the 95 percent confidence bands, which are based on Gaussian approximation of 200 Monte Carlo simulations. 
Figure A4. Impulse-Responses of NPL to Shocks in Bank-Specific and Macroeconomic Variables in the Alternative Model (post-crisis period)

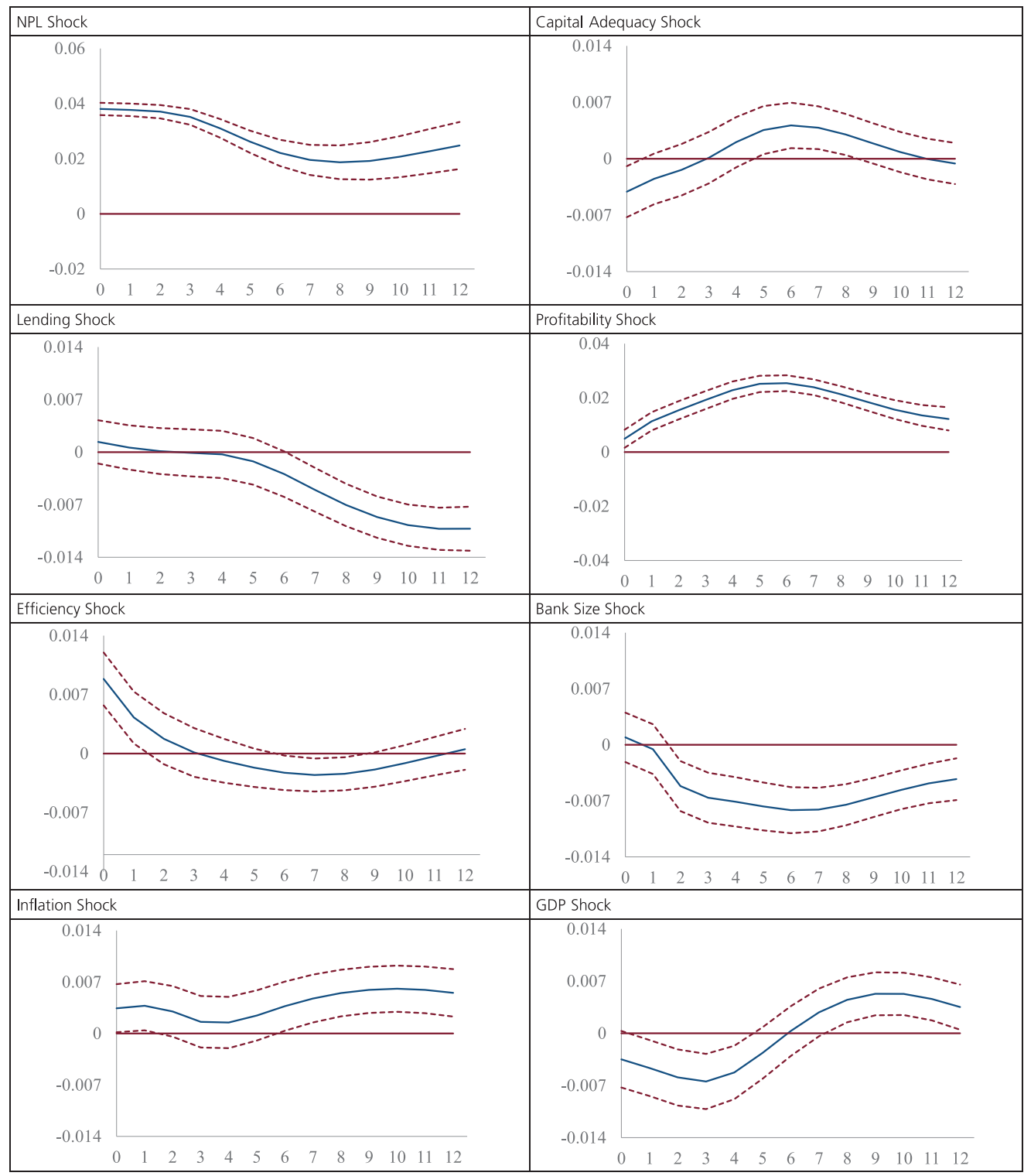


Figure A4. Impulse-Responses of NPL to Shocks in Bank-Specific and Macroeconomic Variables in the Alternative Model (post-crisis period, continued)

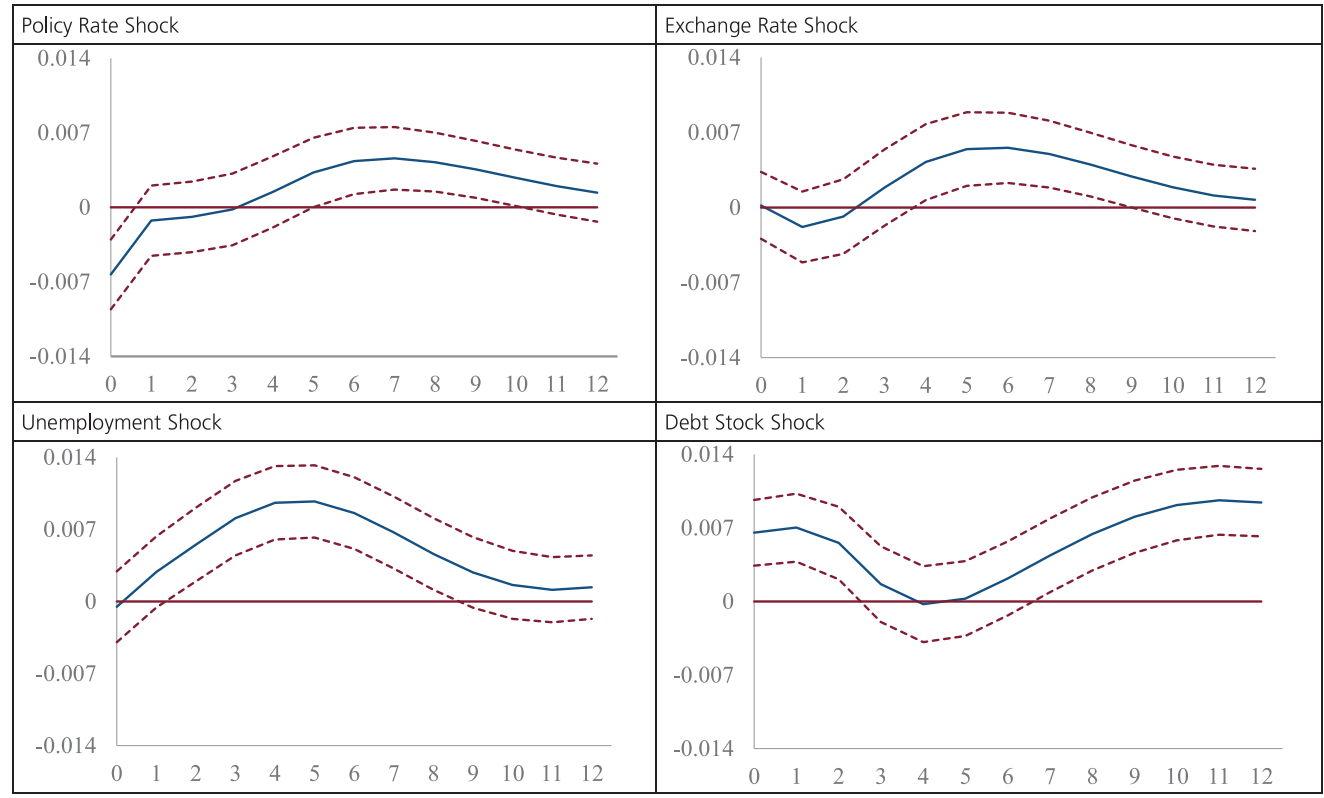

Notes: The blue line shows the impulse-response of NPL to one-unit standard shock in the respective variable over 12 quarters. The red dotted lines are the upper and lower bounds of the 95 percent confidence bands, which are based on Gaussian approximation of 200 Monte Carlo simulations. 


\section{References}

1. Afşar, M., 2011, Küresel Kriz ve Türk Bankacılık Sektörüne Yansımaları (in Turkish), Eskişehir Osmangazi Üniversitesi IïBF Dergisi, 6(2): 143-171.

2. Ahmad, N.H. and M. Ariff, 2007, Multi-Country Study of Bank Credit Risk Determinants, International Journal of Banking and Finance, 5(1): 135-152.

3. Aiyar, S., W. Bergthaler, J.M. Garrido, A. llyina, A. Jobst, K. Kang, D. Kovtun, Y. Liu, D. Monaghan and M. Moretti, 2015, A Strategy for Resolving Europe's Problem Loans, IMF Staff Discussion Note No. 15/19.

4. Akaike, H., 1969, Fitting Autoregressive Models for Prediction, Annals of the Institute of Statistical Mathematics, 21(1): 243-247.

5. Amin, A.S., M.O. Imam and M. Malik, 2019, Regulations, Governance, and Resolution of Non-Performing Loan: Evidence from an Emerging Economy, Emerging Markets Finance and Trade, 55(10), 2275-2297.

6. Andrews, D. and B. Lu, 2001, Consistent Model and Moment Selection Procedures for GMM Estimation with Application to Dynamic Panel Data Models, Journal of Econometrics, 101(1): 123-164.

7. Arellano, M. and O. Bover, 1995, Another Look at the Instrumental Variable Estimation of Error-Components Models, Journal of Econometrics, 68(1): 2951.

8. Bar, R.S., L.M. Seiford and T.F. Siems, 1994, Forecasting Banking Failure: A Non-Parametric Frontier Estimation Approach, Researches Economiques de Lovain, 60(4): 417-429.

9. Barth, J.R., G. Caprio and R. Levin, 1994, Bank Regulation and Supervision: What Works Best?, Journal of Financial Intermediation, 13(2): 205-248.

10. Baş̧̧, E. and H. Kara, 2011, Finansal İstikrar ve Para Politikası (in Turkish), iktisat işletme ve Finans, 26(302): 9-25.

11. Beaton, K., A. Myrvoda and S. Thompson, 2016, Non-Performing Loans in the ECCU: Determinants and Macroeconomic Impact, IMF Working Paper No. $16 / 229$.

12. Belgrave, A., G. Kester and M. Jackman, 2012, Industry Specific Shocks and 
Non-Performing Loans in Barbados, The Review of Finance and Banking, 4(2): 123-133.

13. Berge, T.O. and K.G. Boye, 2007, An Analysis of Bank's Problem Loans, Norges Bank Economic Bulletin, 78(2): 65-76.

14. Berger, A.N. and R. DeYoung, 1997, Problem Loans and Cost Efficiency in Commercial Banks, Journal of Banking and Finance, 21(6): 849-870.

15. Berger, A.N. and C.H.S. Bouwman, 2013, How Does Capital Affect Bank Performance during Financial Crises, Journal of Financial Economics, 109(1): 146-176.

16. Blundell, R. and S. Bond, 1998, Initial Conditions and Moment Restrictions in Dynamic Panel Data Models, Journal of Econometrics, 87(1): 115-143.

17. Bofondi, M. and T. Ropele, 2011, Macroeconomic Determinants of Bad Loans: Evidence from Italian Banks, Bank of Italy Occasional Paper No. 89.

18. Boss, M., G. Fenz, J. Pann, C. Puhr, M. Schneider and E. Ubl, 2009, Modeling Credit Risk through the Austrian Business Cycle: An Update of the OeNB Model, Financial Stability Report, Oesterreichische Nationalbank, 17: 85-101.

19. Boudriga, A., N. Boulila and S. Jellouli, 2009, Does Bank Supervision Impact Nonperforming Loans: Cross-Country Determinants Using Aggregate Data, MPRA Paper No. 18068.

20. Breitung, J., 2002, Nonparametric Tests for Unit Roots and Cointegration, Journal of Econometrics, 108(2): 343-363.

21. Breitung, J. and S. Das, 2005, Panel Unit Root Tests under Cross Sectional Dependence, Statistica Neerlandica, 59(4): 414-433.

22. Breuer, J.B., 2006, Problem Bank Loans, Conflicts of Interest, and Institutions, Journal of Financial Stability 2(3): 266-285.

23. Canova, F. and M. Ciccarelli, 2013, Panel Vector Autoregressive Models: A Survey, ECB Working Paper No. 1507.

24. Castro, V., 2013, Macroeconomic Determinants of the Credit Risk in the Banking System: The Case of the GIPSI, Economic Modelling, 31(c): 672-683.

25. CBRT, 2010, Financial Stability Report, December, available at http://www. 
tcmb.gov.tr/wps/wcm/connect/dae98237-7d57-46fc-9e23-d95c1f191e97/ fulltext11. pdf?MOD=AJPERES\&CACHEID=ROOTWORKSPACE-dae982377d57-46fc-9e23-d95c1f191e97-m3fw7js.

26. Choi, I., 2001, Unit Root Tests for Panel Data, Journal of International Money and Finance, 20(2): 249-272.

27. Cifter, A., S. Yilmazer and E. Cifter, 2009, Analysis of Sectoral Credit Default Cycle Dependency with Wavelet Networks: Evidence from Turkey, Economic Modelling, 26(6): 1382-1388.

28. Demirguc-Kunt, A., 1989, Deposit-Institution Failures: a Review of Empirical Literature, Federal Reserve Bank of Cleveland, Economic Review, 25(4): 2-18.

29. Demirguc-Kunt, A. and E. Detragiache, 1998, The Determinants of Banking Crises in Developing and Developed Countries, IMF Staff Papers, 45(1): 81109.

30. Erdinç, D. and E. Abazi, 2014, The Determinants of NPLs in Emerging Europe, 2000-2011, Journal of Economics and Political Economy, 1(2): 112-125.

31. Espinoza, R. and A. Prasad, 2010, Nonperforming Loans in the GCC Banking Systems and Their Macroeconomic Effects, IMF Working Paper No. 10/224.

32. Fofack, H., 2005, Non-Performing Loans in Sub-Saharan Africa: Causal Analysis and Macroeconomic Implications, World Bank Policy Research Working Paper No. 3769.

33. Ganioğlu, A. and V. Us, 2014, The Structure of the Turkish Banking Sector before and after the Global Crisis, CBRT Working Paper No. 14/29.

34. García-Marco, T. and M.D. Robles-Fernández, 2008, Risk-Taking Behavior and Ownership in the Banking Industry: The Spanish Evidence, Journal of Economics and Business, 60(4): 332-354.

35. Greenidge, K. and T. Grosvenor, 2010, Forecasting Non-Performing Loans in Barbados, Journal of Business, Finance and Economics in Emerging Economies, 5(1): 79-108.

36. Hadri, K., 2000, Testing for Stationarity in Heterogeneous Panel Data, The Econometrics Journal, 21(3): 148-161. 
37. Hamilton, J.D., 1994, Time Series Analysis, Princeton University Press, Princeton, NJ, USA.

38. Hannan, E.J. and B.G. Quinn, 1979, The Determination of the Order of an Autoregression, Journal of the Royal Statistical Society, 41(2): 190-195.

39. Hansen, L., 1982, Large Sample Properties of Generalized Method of Moments Estimators, Econometrica, 50(4): 1029-54.

40. Harris, R.D.F. and E. Tzavalis, 1999, Inference for Unit Roots in Dynamic Panels Where the Time Dimension is Fixed, Journal of Econometrics, 91(2): 201-226.

41. Holtz-Eakin, D., W. Newey and H. Rosen, 1988, Estimating Vector Autoregressions with Panel Data, Econometrica, 56(6): 1371-95.

42. http://www.tuik.gov.tr.

43. https://www.hmb.gov.tr.

44. https://www.tbb.org.tr.

45. https://evds2.tcmb.gov.tr/.

46. Hu, J.L., Y. Li and Y.H. Chiu, 2004, Ownership and Nonperforming Loans: Evidence from Taiwan's Banks, The Developing Economies, 42(3): 405-420.

47. Im, K.S., M.H. Pesaran, and Y. Shin, 2003, Testing for Unit Roots in Heterogenous Panels, Journal of Econometrics, 115(1): 53-74.

48. IMF, 2012, Turkey: Selected Issues, IMF Country Report No. 12/339.

49. Jassaud, N. and K. Kang, 2015, A Strategy for Developing a Market for Nonperforming Loans in Italy, IMF Working Paper No. 15/24.

50. Jiménez, G. and J. Saurina, 2006, Credit Cycles, Credit Risk, and Prudential Regulation, International Journal of Central Banking, 2(2): 65-98.

51. Kalluci, I. and O. Kodra, 2010, Macroeconomic Determinants of Credit Risk: The case of Albania, in A. Fullani (ed.), Economic Policies in SEE: Design, Performance and Challenges, Bank of Albania.

52. Kara, H., 2013, Monetary Policy after the Global Crisis, Atlantic Economic Journal, 41(1): 51-73. 
53. Keeton, W.R. and C.S. Morris, 1987, Why Do Banks' Loan Losses Differ?, Federal Reserve Bank of Kansas City, Economic Review, 72(5): 3-21.

54. Khemraj, T. and S. Pasha, 2009, The Determinants of Non-Performing Loans: An Econometric Case Study of Guyana, MPRA Paper No. 53128.

55. Klein, N., 2013, Non-Performing Loans in CESEE: Determinants and Impact on Macroeconomic Performance, IMF Working Paper No. 13/72.

56. Levin, A., C.F. Lin and C.S.J. Chu, 2002, Unit Root Tests in Panel Data: Asymptotic and Finite-Sample Properties, Journal of Econometrics, 108(1): 1-24.

57. Louzis, D.P., A.T. Vouildis and V.L. Metaxas, 2012, Macroeconomic and BankSpecific Determinants of Non-Performing Loans in Greece: A Comparative Study of Mortgage, Business and Consumer Loan Portfolios, Journal of Banking and Finance, 36(4): 1012-1027.

58. Love, I. and L. Zicchino, 2006, Financial Development and Dynamic Investment Behavior: Evidence from Panel VAR, The Quarterly Review of Economics and Finance, 46(2): 190-210.

59. Love, I. and R.T. Ariss, 2014, Macro-Financial Linkages in Egypt: A Panel Analysis of Economic Shocks and Loan Portfolio Quality, Journal of International Financial Markets, Institutions and Money, 28(C): 158-181.

60. Lütkepohl, H., 2005, New Introduction to Multiple Time Series Analysis, Springer-Verlag GmbH, Heidelberg, Germany.

61. Makri, V., A. Tsagkanos and A. Bellas, 2014, Determinants of Non-Performing Loans: The Case of Eurozone, Panoeconomicus, 61(2): 193-206.

62. Moinescu, B. and A. Codirlaşu, 2012, Assessing the Sectoral Dynamics of Non-performing Loans: Signs from Financial and Real Economy, Theoretical and Applied Economics, XIX(2): 69-80.

63. Nkusu, M., 2011, Nonperforming Loans and Macrofinancial Vulnerabilities in Advanced Economies, IMF Working Paper No. 11/161.

64. Ozili, P.K., 2019, Non-Performing Loans and Financial Development: New Evidence, The Journal of Risk Finance, 20(1), 59-81. 
65. Podpiera, J. and L. Weill, 2008, Bad Luck or Bad Management? Emerging Banking Market Experience, Journal of Financial Stability, 4(2): 135-148.

66. Radivojević, N., D. Cvijanović, D. Sekulic, D. Pavlovic, S. Jovic and G. Maksimović, 2019, Econometric Model of Non-Performing Loans Determinants, Physica A: Statistical Mechanics and its Applications, 520(15), 481-488.

67. Reinhart, C. and K. Rogoff, 2011, From Financial Crash to Debt Crisis, American Economic Review, 101(5): 1676-1706.

68. Rinaldi, L. and A. Sanchis-Arellano, 2006, Household Debt Sustainability What Explains Household Non-Performing Loans? An Empirical Analysis, ECB Working Paper No. 57.

69. Rossi, S., M. Schwaiger and G. Winkler, 2008, Linking Managerial Behaviour to Cost and Profit Efficiency in the Banking Sectors of Central and Eastern European Countries, Kredit und Capital, 41(4): 598-629.

70. Salas, V. and J. Saurina, 2002, Credit Risk in Two Institutional Regimes: Spanish Commercial and Savings Banks, Journal of Financial Services Research, 22(3): 203-224.

71. Schwarz, G., 1978, Estimating the Dimension of a Model, The Annals of Statistics, 6(2): 461-464.

72. Selçuk, B., 2010, Küresel Krizin Türk Finans Sektörü Üzerindeki Etkileri (in Turkish), Ekonomi Bilimleri Dergisi, 2(2): 21-27.

73. Siems, T.F. and R.S. Barr, 1994, Predicting Bank Failure Using DEA to Quantify Management Quality, Financial Industry Studies Working Paper No. 94-1.

74. Sinkey, J.F. and M.B. Greenawalt, 1991, Loan-Loss Experience and RiskTaking Behavior at Large Commercial Banks, Journal of Financial Services Research, 5(1): 43-59.

75. Sorge, M., 2004, Stress-Testing Financial Systems: An Overview of Current Methodologies, BIS Working Papers No. 165.

76. Stern, G.H. and R.J. Feldman, 2004, Too Big To Fail: The Hazards of Bank Bailouts, Brookings Institution Press, Washington, DC, USA.

77. Us, V., 2016, Determinants of Non-Performing Loans in the Turkish Banking 
Sector: What Has Changed after the Global Crisis?, CBT Research Notes in Economics No. 16/27.

78. , 2017, A Dynamic Approach to Analysing the Effect of the Global Crisis on Nonperforming Loans: Evidence from the Turkish Banking Sector, Applied Economics Letters, 24(3): 186-192.

79. 2018, The Determinants of Non-Performing Loans before and after the Crisis: Challenges and Policy Implications for Turkish Banks, Emerging Markets Finance and Trade, 54(7): 1608-1622.

80. Whalen, G., 1991, Proportional Hazards Model of Bank Failure: An Examination of Its Usefulness as an Early Warning Tool, Federal Reserve Bank of Cleveland, Economic Review, 27(1): 21-31.

81. Vithessonthi, C., 2016, Deflation, bank credit growth, and non-performing loans: Evidence from Japan, In ternational Review of Financial Analysis, 45(2016): 295-305. 